九州大学学術情報リポジトリ

Kyushu University Institutional Repository

\title{
A Monograph of the Collignoniceratidae from Hokkaido Part II : Studies of the Cretaceous Ammonites from Hokkaido and Saghalien-XV
}

Matsumoto, Tatsuro

Faculty of Science, Kyushu University

https://doi.org/10.5109/1543628

出版情報：九州大學理學部紀要：Series D, Geology. 16 (3)，pp.209-243，1965-11-20. Faculty of Science, Kyushu University バージョン：

権利関係 : 


\title{
A Monograph of the Collignoniceratidae from Hokkaido
}

\author{
Part II \\ (Studies of the Cretaceous Ammonites from \\ Hokkaido and Saghalien-XV)
}

By

Tatsuro Matsumoto

\begin{abstract}
Part II contains the systematic descriptions of the subfamily Peroniceratinae. In addition to Peroniceras, Gauthiericeras (s. s.), G. (Ciryella) and Reginaites, four new genera are established, with much revision of the previously established genera. The relations of these genera and the origin of the subfamily are discussed on the basis of the author's observations. The described species from Hokkaido are altogether ten:three of Peroniceras, a new one and another of the first new genus, two new ones and another of the second new genus, a new one of the third and the fourth new genus respectively. In connection with the descriptions of the species from Hokkaido, comments are given on some species occurring outside Japan.
\end{abstract}

\section{Contents}

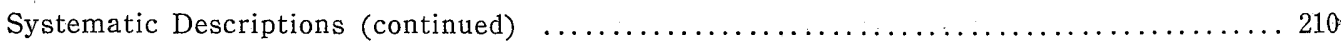

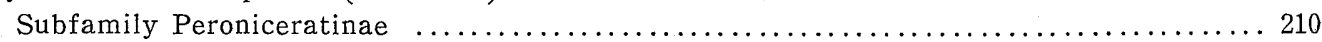

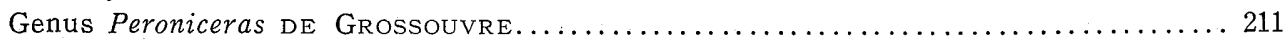

Peroniceras sp. nov. (?) aff. $P$. platycostatum van HoEpen . . . . . . . . . . . . . . . 214

Peroniceras sp. nov. (?) aff. P. czoernigi (Redtenbacher) ................ 216

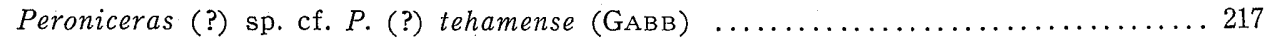

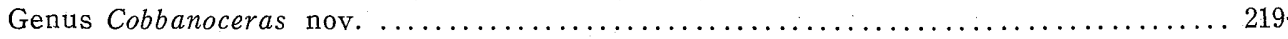

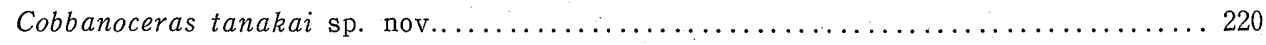

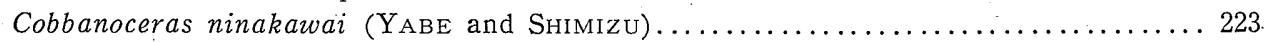

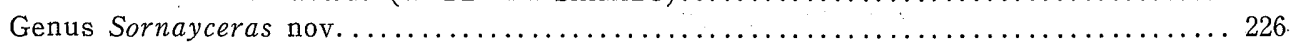

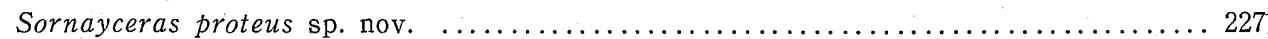

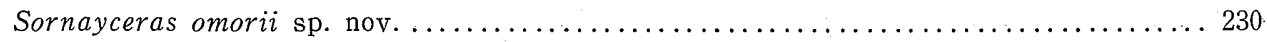

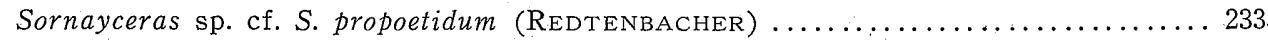

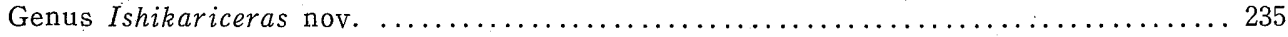

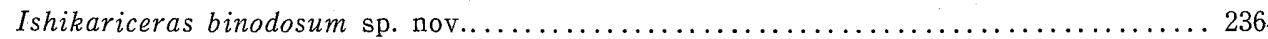

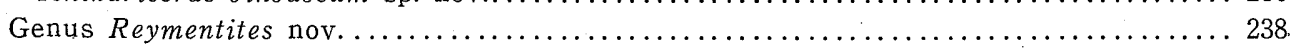

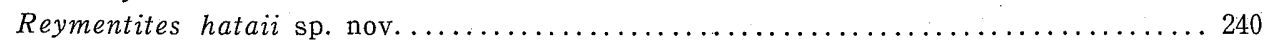

Manuscript received May 1, 1965.

Part I of this monograph was published in the Mem. Fac. Sci., Kyushu Univ., Ser. D, Geol., Vol. XVI, No. 1, pp. 1-80, pls. 1-18, March, 1965. 


\section{Systematic Descriptions}

(Continued)

\section{Subfamily Peroniceratinae}

The subfamily Peroniceratinae HyATT, 1900, are a group of genera typically represented by Peroniceras DE GRossouvre, 1894. This genus is characterized by evolute whorls, distinctly tricarinate venter, bituberculate ribs and deeply incised, particularly specialized sutures. Gauthiericeras DE GROSSOUVRE, 1894, typically has less evolute whorls, an entire or feebly crenate ventral keel with a groove on either side, stronger ventrolateral tubercles, often double umbilical tubercles and simpler, normal collignoniceratid sutures.

Besides Peroniceras and Gauthiericeras (s. s.) there are several species-groups which are closely related to but not quite identical with either. Ciryella WIEDMANN, 1959, may be one of them. It has evolute whorls and bituberculate ribs like Peroniceras but has a unicarinate venter and simple sutures like Gauthiericeras. I would agree with WIEDMANN in treating Ciryella as a subgenus of Gauthiericeras, but contrary to his opinion I consider that Peroniceras is clearly separated from Gauthiericeras (s. l.) by the different pattern of sutures and distinctly tricarinate-bisulcate venter.

As a result of the study of the specimens from Hokkaido, I am establishing four new genera in Peroniceratinae. One of them (Cobbanoceras to be defined below) has evolute whorls and distinctly tricarinate venter like Peroniceras but has much simpler, less specialized sutures. The second new genus (Sornayceras) is closely similar to Gauthiericeras but has sutures as specialized as those of Peroniceras.

In all these genera the adult shell reaches a fairly large size and the ornament persists to the last whorl. A new species from Hokkaido and another from Madagascar have smooth outer whorls, although their inner whorls are somewhat similar to those of Gauthiericeras (Ciryella). To accommodate this kind of species a new genus (Ishikariceras) is established below. It is superficially similar to Yabeiceras TokunAGA and Shimizu, 1926. The latter genus was at one time included in Peroniceratinae, but it has now proved to be closer to Forresteria REESIDE, 1927, of the Barroisiceratinae (see Matsumoto, OBata et al., 1964).

Reginaites REYMENT, 1957, was introduced as a multituberculate subgenus of Peroniceras. This has a tricarinate venter and quadri- or trituberculate ribs on which two ventrolateral tubercles are approximated. Its suture is not of Peroniceras type but of normal collignoniceratid type. Consequently Reginaites is treated here as a distinct genus. It is morphologically closer to the first new genus mentioned above than to typical Peroniceras. At the same time it has some characters which seem to be related to Paratexanites. Young's (1963) opinion that Reginaites is a derivative of Texanites is indeed interesting, but I am inclined to transfer $R$. durhami YouNG to the fourth new genus (Reymentites to be defined below). This new genus is another group of tri- or quadrituberculate and tricarinate species, in which the tubercles are nearly equidistant on the flank and the ventrolateral tubercle is not double. It is, accordingly, somewhat similar to later subgroup of Protexanites or to Texanites on 
one hand and to the first new genus (Cobbanoceras) on the other.

It might be considered that the two, tricarinate and multituberculate genera could be grouped in a new subfamily, which branched from Texanitinae in parallel with Peroniceratinae (s.s.). As the available evidence is not sufficient, they are, for the time being, described in this paper under the Peroniceratinae, which may, thus, be polyphyletic.

While the origin of the Texanitinae is best sought in Subprionocyclus, that of the Peroniceratinae should, in my opinion, probably be ascribed to Prionocyclus of the subfamily Collignoniceratinae. As I have already discussed in Part I, Prionocycloceras Spath, 1926, is apparently intermediate between Prionocyclus and Gauthiericeras. It has at least on its inner whorls double ventrolateral tubercles, of which the inner ones may be exaggerated to form horns on the outer whorl absorbing the outer ones. This character is essentially the same as that of Prionocyclus. In Gauthiericeras the siphonal keel is sometimes finely crenate and strong tubercles are developed at the ventrolateral shoulders, but tubercles are not double at any growth-stage. In the adolescent or middle growth-stage of the type-species, G. margae (ScHLÜTER), as clearly seen in an excellent example of DE GRossouvRE's (1894, p. 90, pl. 15, fig. 2), the umbilical tubercles are double, apparently giving rise to lower lateral tubercles. Whether or not this has connection with the incipient lateral tubercles of certain late species of Prionocyclus (e.g. P. reesidei Sidwell and P. quadratus CoBbAN) is still unsettled. While the siphonal keel is lowered in Prionocycloceras, it keeps its distinctness in Gauthiericeras. In Prionocycloceras ribs and riblets cross the venter forming chevrons, while in Gauthiericeras the ribs end at the ventrolateral tubercles or at the edge of the groove on the sides of the siphonal keel. The edge of the groove in Gauthiericeras and the side keels in Peroniceras and other tricarinate relatives remind us of Prionocyclus on whose venter the projected extension of the fading ribs and riblets join with the edge of a groove on either side of the keel. Stratigraphically Prionocycloceras is almost contemporary with Gauthiericeras, both occurring in the next higher stage (i. e. Coniacian) than Prionocyclus.

Taking all these points into consideration, I am rather inclined to ascribe the origin of Gauthiericeras and other related genera of the Peroniceratinae to Prionocyclus of the Collignoniceratinae. Prionocycloceras is rather to be regarded as a last survival of the Collignoniceratinae derived from Prionocyclus in parallel with Gauthiericeras, Peroniceras, etc., but retaining Prionocyclus-like characters.

In Hokkaido typical examples of Gauthiericeras (s.s.), G. (Ciryella) and Reginaites have not yet been confirmed to occur. The holotype of Gauthiericeras rarum YABE (in Y ABE and ShIMizu, 1925, p. 135, pl. 33, figs. 11-15) is unfortunately missing and I cannot give comments on it. From the description and illustration it does not seem to be a typical Gauthiericeras. Representatives of other genera have been identified as described in the following pages.

\section{Genus Peroniceras DE Grossouvre, 1894}

Type-species.-Peroniceras moureti DE Grossouvre, 1894, from the Coniacian of 
France, by original designation.

Generic diagnosis.-The shell consists of polygyral, evolute, slowly enlarging: whorls, with widely open umbilicus. It often attains to a large size. The whorl section is subquadrate, subrectangular or trapezoidal; with subangular or abruptly rounded shoulders. The venter is distinctly tricarinate and bisulcate. The median keel is smooth and the most prominent. The side keels are normally smooth, although sometimes they may be faintly undulated.

The flank is ornamented with numerous radial ribs, which in some species are mostly single and of equal length and in other species may be bifurcated or show intercalated shorter ribs. The ribs may vary in strength, distance and curvature from one species or growth-stage to another. The ribs are bituberculate. The ventrolateral tubercles are subrounded or somewhat clavate; the umbilical ones are rounded or bullate and sometimes indistinctly double. At the ventrolateral tubercles the ribs are bent forward, broadened and weakened on the venter, fading away as they approach to the side keel. Sometimes the side keel is slightly elevated at the end of the rib, resulting in gentle undulation of the keel itself.

There may be weak spiral lirae on the whorl in some species. They may produce weak crenation on the ribs, though not so distinctly as in certain species of Mortoniceras.

The suture is deeply and finely incised. The lateral lobe $(\mathrm{L})$ is normally the deepest, more or less narrowed at its stem, and apparently multipartite, having a number of narrow and long folioles and lobules. The first lateral saddle between $\mathrm{E}$ and $\mathrm{L}$ is asymmetrically divided by a moderately deep lobule. The second lateral saddle is much narrowed at its stem by the oblique incision of $U_{2}$ and lateral branches of $\mathrm{L}$. Its head is roundish in outline and apparently tripartite or multipartite. From this head through the heads of the auxiliary saddles a remarkably descending alignment is seen to the umbilical seam. The outer subdivision of $U_{3}$ may be extremely oblique in some species.

Remarks.-Besides the type-species ( $P$. moureti), well-known examples of Peroniceras include $P$. subtricarinatum (D'ORBIGNy, 1840), P. tridorsatum (SCHLU̇TER, 1867), $P$. westfalicum (SCHL̇̇TER, 1867), $P$. czoernigi (REDTENBACHER, 1873) and $P$. dravidicum (Kossmat, 1895). There are several other species from various parts of the world. Certain species which were described under Peroniceras will be removed to Cobbanoceras, Sornayceras and Ishikariceras as discussed below.

In spite of the world-wide distribution and frequent occurrence, few species have been precisely studied with respect to the ontogenetic change of characters and the variation within a species. Unfortunately the specimens from Hokkaido are not sufficiently preserved and not numerous enough to study these points. Accordingly specific identification is not definite.

Affinities.-Peroniceras is indeed a well defined genus, but there is some uncertainty in our present knowledge of its ancestry. The three ventral keels might be derived from the serrate median keel and trains of outer ventrolateral clavi of Subprionocyclus, as I once thought (MAтsumoto, 1955). While the inner ventrolateral tubercles tend to be weakend in Subprionocyclus, they remain strong and the outer ventrolateral tubercles tend to be reduced in Prionocyclus, as I explained in Part I of this mono- 
graph. Now the ventrolateral tubercles of Peroniceras seem to correspond with the inner ventrolateral tubercles of Prionocyclus. In such species as Prionocyclus reesidei and $P$. quadratus the projected ventral ribs, with or without outer ventrolateral tubercles, end at the margin of the shallow groove on either side of the finely serrate median keel and the margin of the groove is sometimes slightly elevated especially at the end of the ribs. This feature suggests that the side keel of Peroniceras could originate from the incipient elevation along the margin of the groove in these later species of Prionocyclus. Thus the origin of Peroniceras seems to be more likely in Prionocyclus than in Subprionocyclus. Peroniceras has, however, much more complicated and specialized sutures than Prionocyclus. Therefore the morphological hiatus may be too great to connect Peroniceras directly with Prionocyclus.

In this connection Cobbanoceras, a new genus to be defined below, could be considered as representing an intermediate position, because it has Peroniceras-like shellform and ornamentation but Prionocyclus-like sutures. However, the evidence of stratigraphic succession is not satisfactory.

As another alternative Gauthiericeras (including subgenus Ciryella) is to be con:sidered. It has simpler and less specialized sutures than Peroniceras. Its side keels are not so distinctly developed as in the latter. While Gauthiericeras (s.s.) has less evolute whorls, G. (Ciryella) has as evolute whorls as Peroniceras.

The ontogenetical development of characters in Peroniceras may give evidence for the problem. I have had recently an opportunity to study the illustrated specimen of Peroniceras dravidicum (Kossmat) (1895, p. 190 [94], pl. 23 [9], fig. 3a-d) (Geol. Surv. India Coll. 141), which is designated here as the lectotype. As Kossmat described, three ventral keels are distinct on its outer whorl but on its inner whorl, at diameters below $25 \mathrm{~mm}$., only the median keel is distinct and the side keels are very faint and close to the median keel, separated by narrow and shallow furrows. The venter of the inner whorl is narrower and more roof-shaped than that of the outer. Thus Gauthiericeras-like characters are displayed on the inner whorl of Peroniceras dravidicum. I do not know, however, whether all the species of Peroniceras show the same type of ontogeneric change or not.

The difference in the pattern of suture is again great between Gauthiericeras and Peroniceras. In this respect Sornayceras, a new genus to be established below, may occupy at least morphologically an intermediate position between Gauthiericeras and Peroniceras. In fact the type-species of Sornayceras, to be described below, resembles Peroniceras westphalicum in lateral view and is distinguished by the character of the venter. The evidence of stratigraphic occurrence is, however, insufficient to lead the final conclusion about this postulated line of descent.

To sum up, the ultimate origin of Peroniceras is probably in Prionocyclus, but there is some uncertainty about the details of the line of evolution. Peroniceras, Gauthiericeras (s.s.), Gauthiericeras (Ciryella) and Sornayceras were perhaps derived almost simultaneously from the common ancestor Prionocyclus. Further stratigraphical as well as morphological evidence is needed.

Lastly the resemblance between Peroniceras and Lower Jurassic Arietites is example of heterochronous homoeomorphy. 
Distribution.-Peroniceras is world-wide in the Coniacian.

\author{
Peroniceras sp. nov. (?) aff. P. platycostatum van HOEPEN \\ P1. 36 [19], Fig. 1 ; Text-figs. 1, 2
}

Material.-A single specimen, GK. H5494, from Hobetsu (Coll. W. Hashimoto, kindly presented to Kyushu University).

Description.-Nearly a half whorl, with a diameter of about $180 \mathrm{~mm}$. is preserved. It is mostly septate and a portion of the body-chamber is attached. The inner whorl. is not well preserved.

The umbilicus is about 40 percent of the entire whorl diameter. It is shallow and bordered by a low but steep wall and an abruptly rounded umbilical shoulder. The whorl enlarges rather slowly. It is compressed, being much higher than broad. The flanks are flat and nearly parallel. The venter is very gently arched and gradually passes to the sloping ventrolateral shoulders. It is tricarinate and bisulcate; the median keel is moderately strong but not very prominent; the grooves are moderately broad but shallow; the side keels are low.

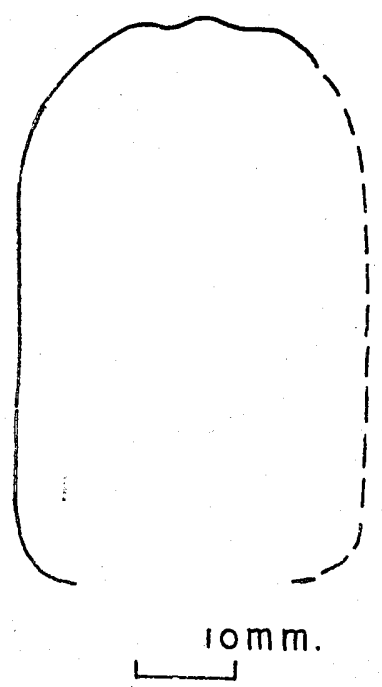

Fig. 1 [41]. Peroniceras sp. nov. (?) aff. P. platy. costatum VAN HOEPEN. Whorl section of GK.H 5494, from Hobetsu, south central Hokkaido.

(T.M. delin.)

The ribs are fairly broad and very low, nearly rectiradiate or slightly prorsiradiate, and alternately long and short. The shorter ones are inserted between or sometimes branched from the longer ones. The umbilical tubercles are low and bullate. The ventrolateral tubercles are broadly rounded and rather low. The ventral ribs. which project from the ventrolateral tubercles are very weak, fading away before they reach the side keel. There are 19 ventrolateral tubercles within a half whorl.

The suture is deeply and finely incised, having the particular pattern of Peroniceras type. The ventral lobe (E) is fairly deep, with the deep lobule on the groove. The first lateral saddle, between $\mathrm{E}$ and $\mathrm{L}$, is subrectangular in a rough outline, asymmetrically divided by a narrow lobule, with the inner branch much narrower than the outer one, the latter of which, in turn, is bipartite; the inner branch is much narrowed by the incision of the lobules on both sides. The lateral lobe $(\mathrm{L})$ is the deepest, very narrow at the stem, and multipartite, having 8 or 7 long lobules. Its bottom is asymmetrically bipartite but may be modified from a suture to another. The second lateral saddle is much narrowed at its stem by the deep. incisions of lobules of $\mathrm{L}$ and $\mathrm{U}_{2}$. Its head is apparently tripartite by two major lobules; its median branch is the largest, highest and further bipartite. The top of the second lateral saddle is somewhat higher than that of the first and forms a strongly descending line with the auxiliaries. $\mathrm{U}_{2}$ is considerably oblique and nearly a half as small as $L$. A subdivision of $U_{3}$ (which may be called $U_{4}$ ) is much oblique 
and slightly larger than half the size of $\mathrm{U}_{2}$.

Measurements (in millimeters).--

$\begin{array}{cccccc}\text { Specimen } & \text { Diameter } & \text { Umbilicus } & \text { Height } & \text { Breadth } & \text { B./H. } \\ \text { GK. H5494 } & c .180(1) & 72.5(0.40) & 58.0 & 18.0 \times 2 & 0.62 \\ \text { " (-1/3 vol.) } & - & - & 47.0 & 15.4 \times 2 & 0.65\end{array}$

Affinities.-The described specimen is similar to certain already described species. but has some distinct characters. Therefore it probably represents a new species, but I hesitate to propose a new specific name, because it is incompletely preserved and only a single specimen.

It resembles the holotype of Peroniceras platycostatum van HoEPEN (1955, p. 367.

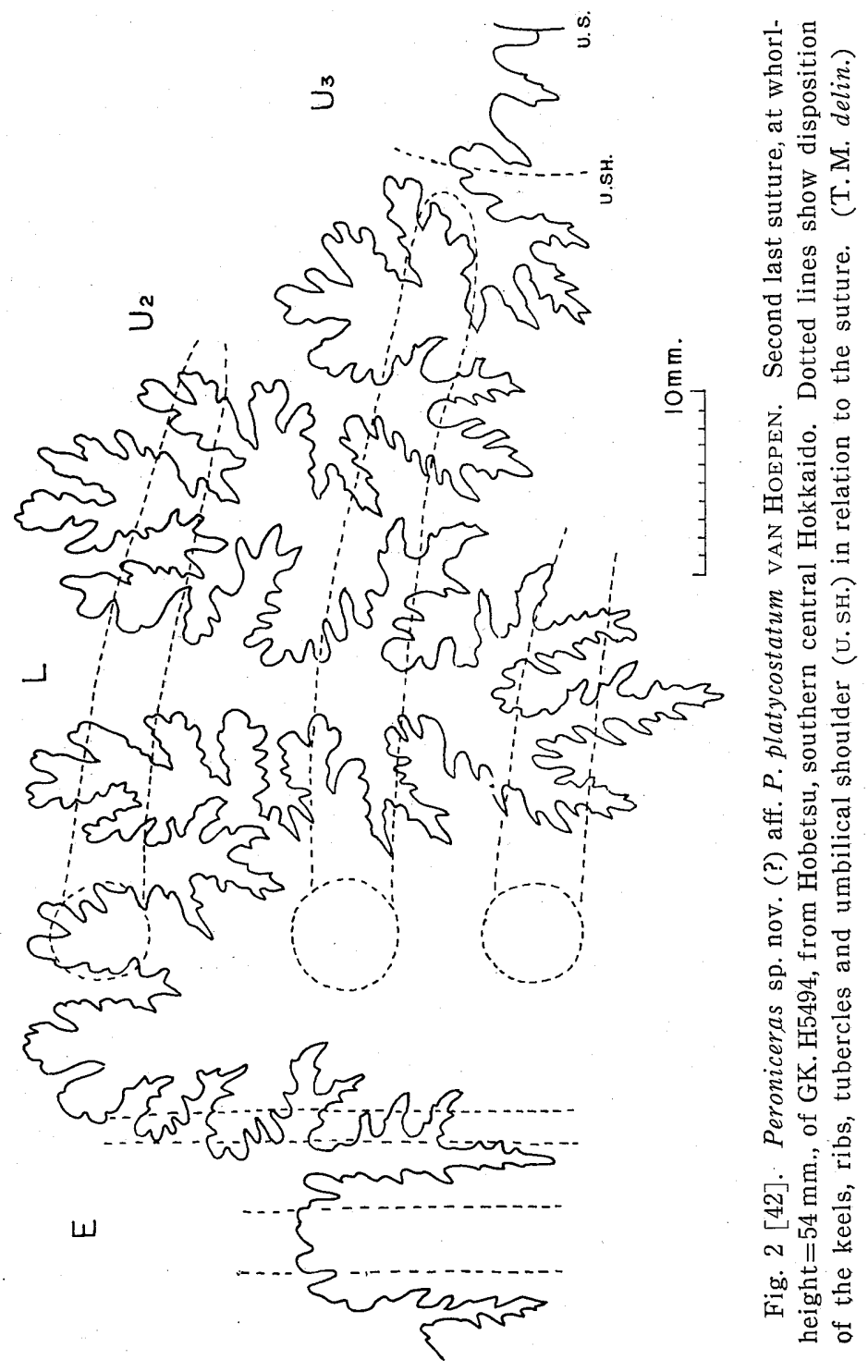


text-figs. 15-17), from the Coniacian of Zululand, in the compressed whorl, flat flanks, rather low ventral keels, shallow grooves, broad and low ribs, as well as the pattern of sutures. The South African specimen has, however, somewhat convergent, instead of parallel flanks, a less broadly arched venter and less frequent short ribs than ours. The specimen from Hokkaido probably represents a distinct species which is closely allied to that South African species.

In lateral view the described specimen considerably resembles one of the French specimen described and illustrated by DE. GROSSOUVRE as Gauthiericeras bajuvaricum (1894, p. 88, pl. 9, fig. 1), in the mode of coiling, flat flanks, very weak ribs, configuration and strength of tubercles, and complicated sutures, Although the ventral view of that French specimen was not illustrated, it does not show the three ventral keels so distinctly as the Japanese specimen. It is probably an example of Sornayceras and not a Peroniceras.

Peroniceras haasi Young (1963, p. 72, pl. 34, figs. 3, 4; pl. 35, figs. 1-3), from the Lower Coniacian of Texas, seems to be more closely allied to P. platycostatum vAN Hoepen than to $P$. subtricarinatum (D'ORBIGNY) and P. westphalicum (ScHLŨTER) in the flat flanks and low, weak ribs. In this respect the specimen from Hokkaido is somewhat allied to the species from Texas but is distinguished by the frequent occurrence of shorter ribs.

Occurrence.-The described specimen came, according to the information given by Professor W. Hashimoto, from his loc. 11-2506, Hobetsu, Iburi Province. It is in a area of the Upper Yezo Group, but the geologic structure is so complicated that its precise stratigraphic position is yet uncertain. The fossil was contained in a finegrained calcareous nodule of mudstone.

\section{Peroniceras sp. nov. (?) aff. P. czoernigi (REDTEnBACHeR) P1. 37 [20], Fig. 1}

Material.-A single specimen, Mikasa High School Collection No. 119, from the Ikushumbets area.

Description.-The specimen is small, about $42 \mathrm{~mm}$. in diameter, and is probably immature. It is incompletely preserved and somewhat deformed.

The whorl enlarges somewhat more rapidly than in normal species of Peroniceras. The umbilicus is about 40 percent of the diameter, surrounded by a very low wall. The whorl is higher than broad and subrectangular in section, having rather flat and nearly parallel flanks. The venter is narrow, gently arched and tricarinate-bisulcate. The median keel is more prominent than the side keels. The latter are fairly close to the former, separated by a narrow groove. The ribs on the flank are nearly rectiradiate or slightly prorsiradiate and gently concave. They are numerous, about 17 within a half whorl, separated by interspaces as narrow as or slightly broader than the ribs themselves. They are of moderate strength, ridge-like and not flattened on top. They are mostly simple and there are a few intercalated, shorter ribs. The umbilical tubercles are rather weak and bullate. The ventrolateral tubercles are moderately strong and clavate on top. From them the ribs are projected on the venter 
and fade away as they join with the side keel.

The suture is unfortunately only partly exposed. It seems to be fairly finely incised, but the lateral lobe $(\mathrm{L})$ is not so narrow as in typical species of Peroniceras.

Measurements.-

$\begin{array}{lccccc}\text { Specimen } & \text { Diameter } & \text { Umbilicus } & \text { Height } & \text { Breadth } & \text { B./H. } \\ \text { MHS. } 119 & 41.5(1) & 17.2(0.41) & 15.5(0.37) & 12.5(0.30) & 0.80\end{array}$

Affinities.-The described specimen probably represents a new species which is allied to Peroniceras czoernigi (REDTENBACHeR) (1873, p. 105, pl. 23, fig. 4a-c) (REYMent, 1958 b, p. 38 , pl. 4, figs. 1a-b, 2 ; pl. 5, fig. 2 ; text-fig. $5-1$, from the Coniacian part of the Gosau beds of the Alps. I would agree with REYMENT in considering that the specimen described by Grossouvre (1894, p. 103, pl. 11, fig. 2a, b) as Peroniceras czoernigi, from the Coniacian of France, was not quite identical with the lectotype of that species from the Alps. The specimen from Hokkaido is just intermediate in the density of ribs and enlargement of whorls between the Alpine and French specimens. Since it is single and imperfectly preserved, I hesitate to propose a new name for it. The possibility of subspecific distinction should be considered if further material becomes available.

It is interesting to note here that the suture of Peroniceras czoernigi, as illustrated by RedTEnbacher (1873, pl. 23, fig. 4c) and Reyment (1958b, text-fig. 3-1), seems to have somewhat broader lateral lobe in which folioles and lobules are somewhat shorter than the normal species of Peroniceras. Its second lateral lobe is considerably narrowed and the auxiliaries is remarkably descending as in the typical suture of Peroniceras.

Occurrence.-The locality of this interesting specimen is not precisely recorded. It was found by a schoolboy from Mikasa High School in a dark coloured calcareous nodule as one of the floats in the stream of the Ikushumbets, Ishikari Province, central Hokkaido.

\section{Peroniceras (?) sp. cf. P. (?) tehamense (GABB)}

Text-fig. 3 [43]

Compare.-

1864. Ammonites subtricarinatus, GabB (non D’OrbignY), Paleontology of California, vol. 1, p. 60 , pl. 10, fig. 4 , 4 a.

1869. Ammonites tehamensis GABB, Paleontology of California, vol. 2, p. 132.

?1894. Peroniceras rousseauxi DE Grossouvre, Mém. Expl. Carte Géol. détail. France, 1873, p. 102, pl. 11, fig. 5 .

1958. Peroniceras tehamense, Anderson, Geol. Soc. Amer. Memoir 71, p. 260, pl. 62, fig. 7, 7 a.

1959. Përoniceras tehamense, Matsumoto, Mem. Fac. Sci., Kyushu Univ. ser. D, special vol. 1 , p. 123 , text-figs. 67,68 .

Material.-A fragmentary whorl in the collection of T. MuRamoto, from the Ikushumbets valley.

Description.-The whorl is subquadrate in section, broader than high, about $18.5 \mathrm{~mm}$. in height and $23 \mathrm{~mm}$. in breadth in costal section, and broadest between the umbilical tubercles. The venter is distinctly tricarinate; the median keel is the most prominent 


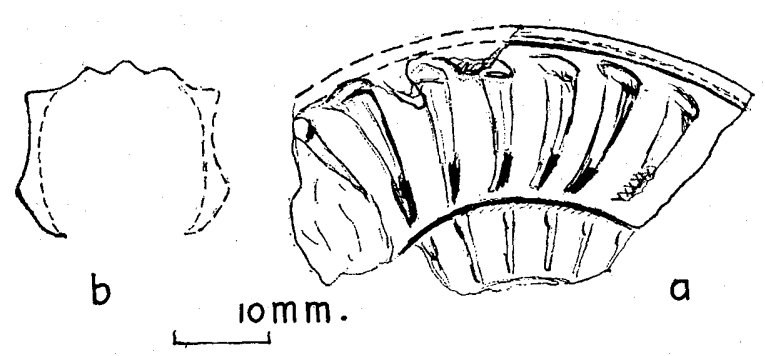

Fig. 3 [43]. Peroniceras (?) sp. cf. P. (?) tehamense (GABB). Lateral view (a) and restored whorl-section (b). A sketch of a specimen in Muramoto's collection from the Ikushumbets.

(T.M. delin.)

and separated from the side keels by moderately broad furrows.

The ribs on the flank are strong, somewhat concave, slightly prorsiradiate, and separated by the interspaces slightly broader than the ribs themselves. They are single, as far as the preserved piece is concerned. The umbilical bullae are fairly elevated and heighest at a point somewhat above the umbilical margin. The ventrolateral tubercles are prominent, rounded at the base and somewhat clavate at the top.

Sutures are not well exposed.

Comparison.- The observable characters closely resemble those of Ammonites tehamensis $\mathrm{GABB}, 1869$, from California, but identification is not certain.

I once referred Ammonites tehamensis to Peroniceras, because it has evolute whorls, a tricarinate venter and bituberculate radial ribs. The suture of this species is, however, only imperfectly known. Of the three syntypes of GABB in the Paleontological Museum of the University of California, Berkeley, UC. 12102, without suture, is probably a body-whorl, UC. 14851 is too fragmentary and small, and only UC. 14850 , the original of GABB's illustration (1864, pl. 10, fig. 4a) has an imperfectly preserved septum at the posterior end. The exposed suture is too imperfect to decide whether it is of typical Peroniceras pattern or it is as simple as the suture of Cobbanoceras (to be described below).

As I have already suggested (Matsumoto, 1959c, p. 123), Peroniceras rousseauxi DE GFOSSOUVRE (1894, p. 142, pl. 11, fig. 5), from the Coniacian of France, is possibly identical with Ammonites tehamensis GABB. The single illustrated specimen of GrosSOUVRE is again fragmentary and its suture was not described nor illustrated. The specimen from Hokkaido does not give good evidence either for the solution of this question.

Whether Ammonites tehamensis GABB belongs to Peroniceras or Cobbanoceras or otherwise has, thus, remains questionable.

Occurrence.-The described specimen was collected by T. Muramoto as one of the calcareous concretions in floats on a bank (called Naka-no-shima) of the main stream of the Ikushumbets, at Shimo-Katsurazawa near the town of Ikushumbets, Ishikari Province, central Hokkaido. Damesites damesi, Tetragonites glabrus and Polyptychoceras yubarense were contained in the same nodule. The derivation is not exactly known, being only presumed to be in some part of the Urakawan (Coniacian 
and Santonian). The locality record of the Californian species is uncertain.

\section{Genus Cobbanoceras nov.}

Etymology.-Dedicated to Dr. W. A. CoBban of the U.S. Geological Survey, Denver, who has made a great contribution to our knowledge of Cretaceous stratigraphy and palaeontology.

Type-species.-Cobbanoceras tanakai sp. nov., to be described below, from the Upper Urakawan (Santonian) of Hokkaido.

Generic diagnosis.-The shell is fairly large, consisting of numerous evolute whorls, with an open umbilicus. The whorl is subquadrate in section and provided with three entire keels on the venter; the median keel are higher than the side keels, being separated by distinct grooves.

The radial ribs on the flank are mostly single, with some intercalated shorter ones, and straight or arcuate. Each rib has an umbilical and a ventrolateral tubercle. From the ventrolateral tubercle the rib runs somewhat forward, weakening and broadening, and ends at the margin of the side keel.

The suture is rather simple; saddles are massive and fairly broad; minor incisions. are small and not deep, with few or no further subdivisions. The first lateral saddle, between $\mathrm{E}$ and $\mathrm{L}$, is asymmetrically divided. The lateral lobe, $\mathrm{L}$, is bipartite at the bottom.

Remarks.-In addition to the type-species, Peroniceras ninakawai $\mathrm{YABE}$ and. SHIMIzU, 1925, is referable to Cobbanoceras. There may be other examples among so-called Peroniceras occurring outside Japan, but they cannot be confirmed without seeing the pattern of sutures. For instance, Ammonites tehamensis GABB, 1869, might be a Cobbanoceras, as has been explained in the preceding pages.

Affinities.-In shell-form and ornamentation Cobbanoceras is very similar to Peroniceras, but they are clearly distinguished from each other by different pattern of sutures. In Cobbanoceras the suture is simple, following the general pattern of Collignoniceratidae, such as Collignoniceras, Prionocyclus and Texanites. In Peroniceras it is much complicated, with deep and multiple incisions, and is considerably modified, with narrowed saddles and lobes, oblique disposition of the auxiliary lobes and strongly descending auxiliaries.

In the less specialized suture, evolute whorls and bituberculate ribs Cobbanoceras. is similar to Gauthiericeras (Ciryella) WIEDMANN, 1959, but the former is distinguished from the latter by its clearly tricarinate-bisulcate, instead of monocarinate, venter.

In the tricarinate venter, evolute whorls and less specialized suture Cobbanoceras resembles Reginaites REYMENT, 1957, but the latter is multituberculate in more or less late growth-stages.

It should be noted here that Cobbanoceras is similar to the earlier subgroup of Protexanites Matsumoto, 1955, of the Texanitinae. If the train of ventral clavi of Protexanites became continuous, the side keel of Cobbanoceras would be produced. The two genera are fairly similar to each other in the young stage and have the same type of suture. The Santonian age of the type-species of Cobbanoceras suggests the possibility of such an interpretation. 
On the other hand an immature specimen of Cobbanoceras from the Coniacian of California, which I provisionally called Peroniceras sp. (MATsumoto, 1959c, p. 123, pl. 31 ; fig. 6a, b; Text-fig. 10 in this paper), shows a wavy weak side keel on its inner whorl at the end of the projected ventral ribs. This feature can be regarded as intimately connected with the incipient elevation at the end of the ribs along the ventral grooves on either side of the median keel in such species as Prionocyclus reesidei Sidwell (1932) and Prionocyclus quadratus CoBBAN (1953). The Californian species has simple sutures like those of Prionocyclus and is a good example of Cobbanoceras. (For further remarks on this species see the description of Cobbanoceras ninakawai.) To sum up, this fact seems to support the view that Cobbanoceras was derived from Prionocyclus in parallel with Gauthiericeras.

Distribution.-The type-species occurred in the Upper Urakawan (approximately Santonian) of Hokkaido. Another species came from the Urakawan of Hokkaido. An example mentioned above was in Member IV (probably Coniacian) of the Redding area, Californian. Further study is necessary to make clear the true extent of geographical distribution and stratigraphical range of Cobbanoceras.

Cobbanoceras tanakai sp. nov.

Pl. 37 [20], Fig. 3 ; Pl. 38 [21], Fig. 1; P1. 39 [22], Fig. 1; Text-figs. 4 [44], 5 [45]

Material.-Holotype is GK.H5522, an internal mould and a part of the external mould, from loc. NH279-a on the Obirashibe, unit Uf, Upper Yezo Group (Coll. K. TANAKA). A paratype, GK. H5523, is an incomplete but larger specimen, from loc. NH671, Obirashibe valley (Coll. K. TANAKA).

The specific name is dedicated to Dr. Keisaku TANAKA, of the Geological Survey

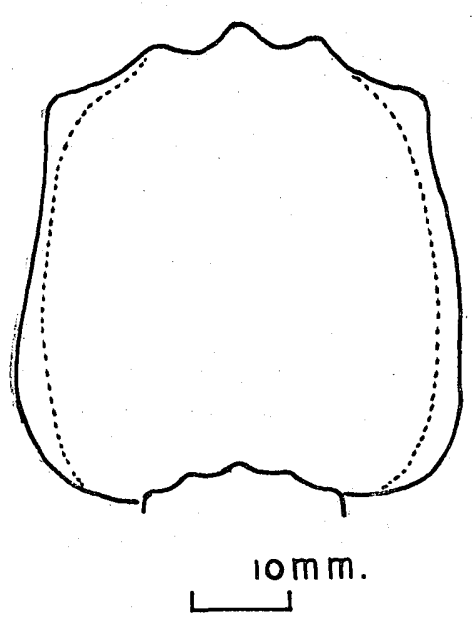

Fig. 4 [44]. Cobbanoceras tanakai gen. et sp. nov. Whor1 section of the holotype, GK. H 5522 , from loc. NH. $279-\mathrm{a}, \mathrm{Obi}$ rashibets, northwest Hokkaido.

(T.M. delin.) of Japan, who kindly supplied me with these and other interesting specimens from his collection along with necessary information about their occurrence.

Diagnosis.-The holotype is about $140 \mathrm{~mm}$. in diameter, but there is a trace of still one more whorl. The paratype was probably about $200 \mathrm{~mm}$. in diameter, although it is now incomplete. Thus, the shell of this species must have reached a rather large size.

The whorl is polygyral and rather evolute, with an umbilicus slightly over 40 percent of the entire shell diameter. It is subquadrate in section, slightly higher than broad, with gently inflated flanks and a broadly arched venter. The umbilical shoulder is subangular in costal section and subrounded in intercostal section. The umbilical wall is steep, being nearly vertical or even somewhat overhung.

The venter has three distinct keels of which the median one is higher and broader than and separated by broad and moderately deep grooves from the 
lateral ones. The ventrolateral shoulder is angular in costal section but sloping in intercostal section.

The flank is ornamented with bituberculate radial ribs. They begin to appear already at a diameter of a few millimeters and persist to the last whorl. The ribs are mostly single; shorter intercalated ones are only occasionally seen on the immature whorls. They are fairly strong and gently concave on the septate whorls and very strong and remarkably concave on the adult body-whorl; they are rursiradiate on the inner half of the flank and especially so near the umbilical margin. The interspaces are somewhat broader than the ribs. The umbilical tubercles are bullate and indistinctly double, with a minor elevation or angulation at the umbilical margin and a more distinct elevation above it at the lower lateral point. On the outer whorl they may be absorbed into the strong ribs. The ventrolateral tubercles are prominent and somewhat clavate on top. From them the ribs are extended with broadening, weakening and forward bend and end at the lateral keel. The lateral keel may be slightly wavy on account of the slight elevation on the extension. of the broadened ribs, but the ribs. never cross the groove and the median keel.

The suture is comparatively simple, consisting of $E, L, U_{2}, U_{3}, U_{1}$ and $I . E$ is deep and of moderate breadth; $\mathrm{L}$ is slightly smaller than $\mathrm{E}$ and is bipartite at the bottom by a small foliole. $U_{2}$ is about a half as small as $\mathrm{L}$ and somewhat oblique; $\mathrm{U}_{3}$ is very small and situated nearly on the umbilical seam; $U_{1}$ is very narrow, vertical and nearly as deep as $\mathrm{U}_{2} ; \mathrm{I}$ is fairly narrow and deep. The first lateral saddle between $\mathrm{E}$ and $\mathrm{L}$ is the broadest, subquadrate in general outline, asymmetrically bipartite by a fairly deep lobule which is situated between the side keel and the

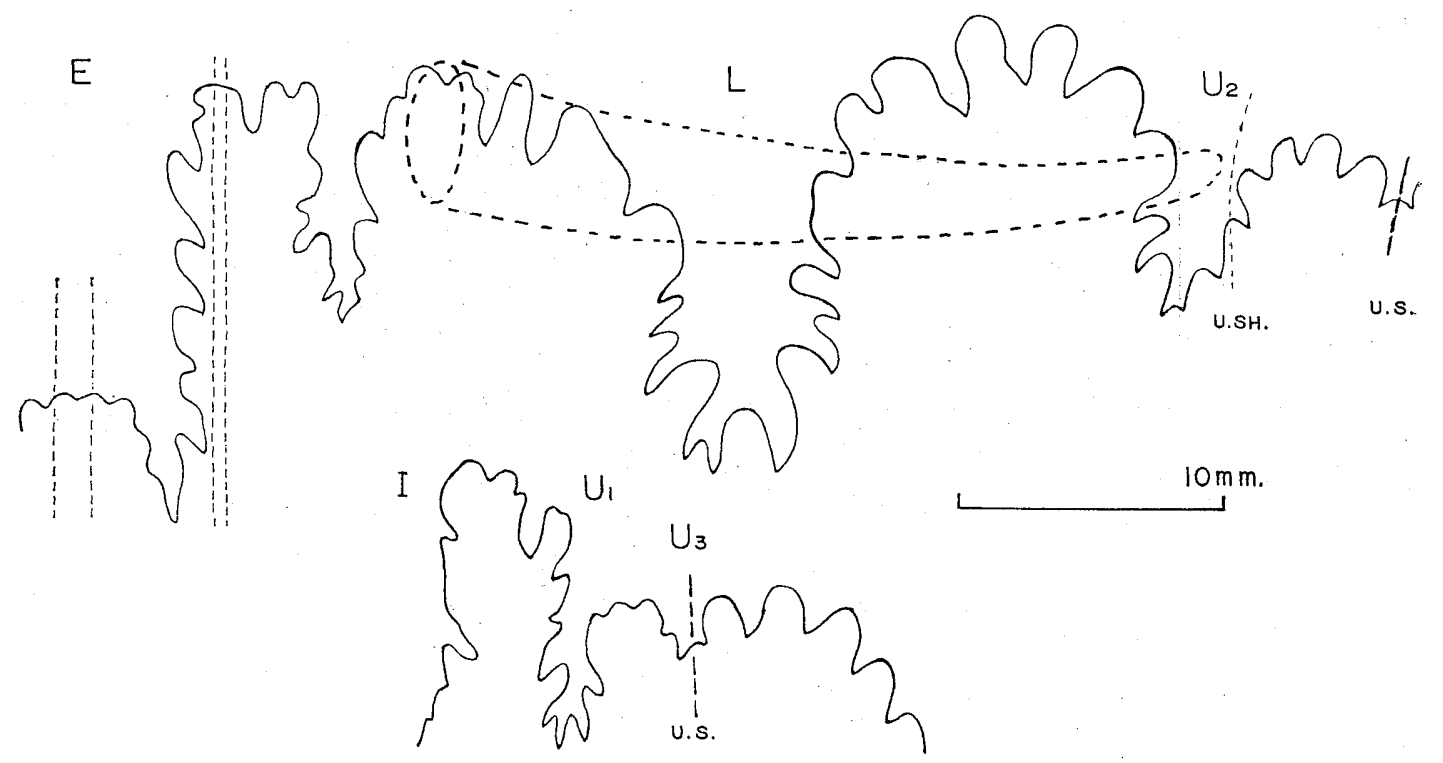

Fig. 5 [45]. Cobbanoceras tanakai gen. et sp. nov. The second last suture, at whorlheight $=40 \mathrm{~mm}$., of the holotype, GK. H5522, from loc. NH. 279-a, unit Uf of TANAKA, Obirashibets area, northwest Hokkaido. External (above) and internal (below) suture. (T.M. delin.) 
ventrolateral tubercle. The second lateral saddle between $L$ and $U_{2}$ is also massive, farirly broad, and dome shaped in general outline. The saddles between $\mathrm{U}_{2}$ and $\mathrm{U}_{3}$ and also $U_{3}$ and $U_{1}$ are lower than other saddles. That between $U_{1}$ and $I$ is fairly high and narrow, being asymmetrically divided by a small lobule which is situated closer to $U_{1}$. All the saddles and lobes have small incisions, which are not deep and scarcely subdivided, except for a fairly deep lobule dividing the saddle between $\mathrm{E}$ and $\mathrm{L} . \mathrm{U}_{3}$ is so small that it does not seem much different from the lobules on the saddle between $\mathrm{U}_{2}$ and $\mathrm{U}_{3}$.

$\begin{array}{cccccc}\begin{array}{c}\text { Measurements. } \\ \text { Specimen }\end{array} & \text { Diameter } & \text { Umbilicus } & \text { Height } & \text { Breadth (costal) } & \text { B./H. } \\ \text { GK. H5522 } & 138.5(1) & 57.0(0.41) & 48.5(0.35) & 45.5(0.33) & 0.93 \\ \text { "I (-1/4 vol.) } & 109.0(1) & 45.5(0.42) & 40.8(0.37) & 38.5(0.35) & 0.95 \\ \text { GK.H } 5532 \text { (somewhat eroded) } & - & 59.0 & 53.5 & 0.90\end{array}$

Affinities.-The present species is similar to Peroniceras moureti DE GROSSOUVRE (1894, p. 100 , pl. 11, figs. 3, 4a-c, text-figs. 37,39$)$, the type-species of Peroniceras, from the Lower Coniacian of France, Germany (?) (SchlÚTER, 1876, p. 158, pl. 41, figs. 3-5) and Texas (?) (Young, 1963, p. 73, pl. 26, fig. 5; pl. 27, fig. 1; text-fig. 13a), in shell-form and ornamentation. In the present species the ribs are somewhat coarser than in that species and they are characteristically rursiradiate on the inner half of

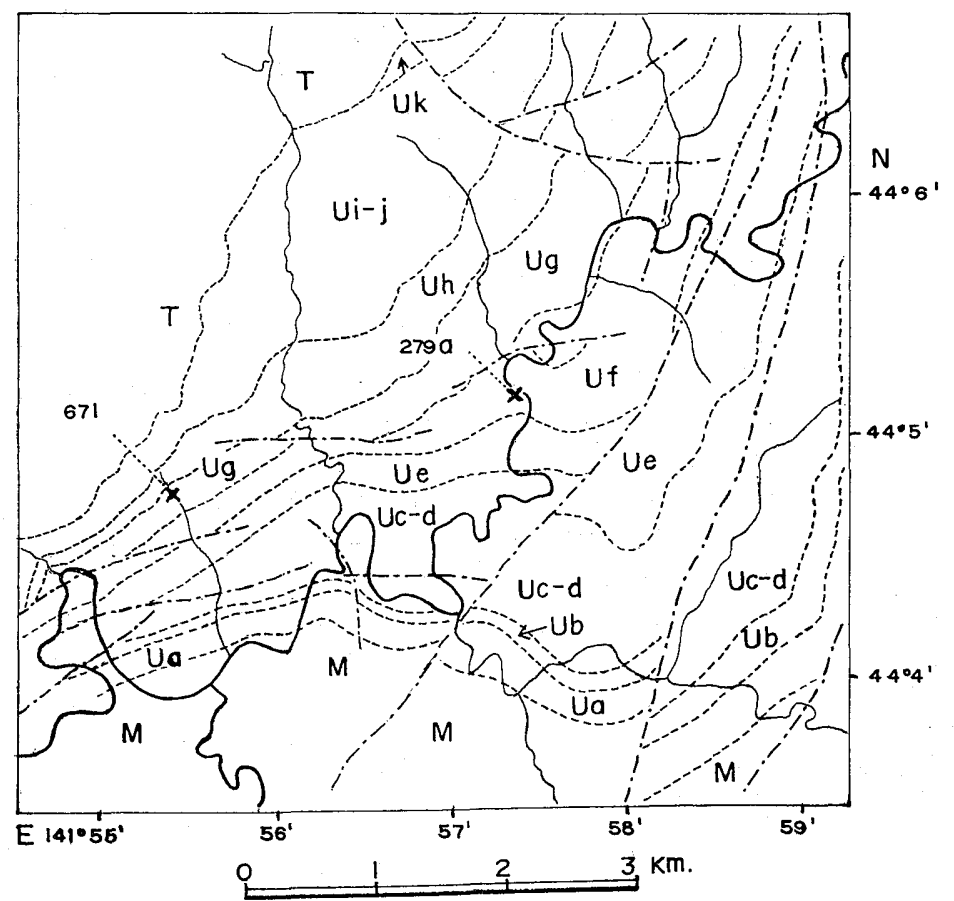

Fig. 6 [46]. Map indicating the localities of Cobbanoceras tanakai gen. et sp. nov., based on the information kindly provided by Dr. Keisaku TANAKA. For the geology see Tsushima et al. 1958. M: Middle Yezo Group, Ua-Uk: Subdivisions of the Upper Yezo Group, T: Tertiary. 
the flank. The unmistakable criterion to distinguish the two species lies in the suture. The present species has much simpler, less incised sutures with more massive, broader saddles as compared with the finely and deeply incised ones with slender, much narrowed elements and strongly descending auxiliaries of $P$. moureti. In the available material no intermediate forms are found in this respect, although Peroniceras czoernigi (REDTEnBecher, 1873) has somewhat atypical features (see p. 217). Anyhow, the above distinction in the pattern of suture is of more than specific significance and is the basis of the separation of the new genus Cobbanoceras.

The comparison with Cobbanoceras ninakawai (YABE and SHIMIzU) is mentioned in the description of that species (page 224).

Occurrence.-The type-locality is NH279a of TANAKA, on the Obirashibets [Obirashibe] in the Tappu quadrangle, unit Uf (fine-sandy siltstone) of the Upper Yezo Group, Rumoi area, Teshio Province, northwest Hokkaido (Fig. 6).

Another locality is NH671, on a branch (Forestry Section 179) of the Obirashibe, in the Tappu quadrangle, unit $\mathrm{Ug}_{1}$ (mudstone) of the same group.

From the type-locality K. TANAKA obtained Inoceramus ezoensis and Inoceramus naumanni and from the nearby localities in the same unit Uf Inoceramus amakusensis. Inoceramus uwajimensis, an index of the Lower Urakawan (Coniacian), occurs in units Ud (lower and middle parts), Uc, Ub and Ua (upper part). From these and other facts, TANAKA (1963; 1958 in Tsushima et al.) referred units Uf and Ug to the Upper Urakawan $[\mathrm{K} 5 \beta]$, approximately Santonian. I agree with him in this conclusion of correlation.

\section{Cobbanoceras ninakawai (YABE and SHIMIZU)}

P1. 37 [20], Fig. 2; Text-figs. 7 [47], 8 [48]

1925. Peroniceras ninakawai Y $\mathrm{ABE}$ and SHmizu, Sci. Rep. Tohoku Imp. Univ., ser. 2, vol. 7, p. 137 . [13], pl, 31 [2], figs. 8, 9; pl. 33 [4], fig. 17.

Material.-Holotype, by original designation, is IGPS. 8026 (Coll. NinaKawA). It is in part secondarily compressed. No more examples have been found in the subsequent collections.

Diagnosis.-The shell is discoidal, consisting of polygyral, slowly enlarging whorls, with little involution. The umbilicus is open and wide, occupying more than 40 percent of the entire shell diameter. The whorl is subquadrate in section, nearly as broad as high, with roughly parallel flanks and a broadly arched, distinctly tricarinate venter. The median keel is somewhat higher than and separated by a groove from the lateral ones; they are entire.

The flank is ornamented with simple, nearly rectiradiate ribs, which are separated by wider interspaces. Each rib is provided with a small, conical tubercle somewhat above the umbilical margin and a prominent ventrolateral tubercle which is clavate on top. From the ventrolateral tubercle the rib is bent forward and extends up to the margin of the lateral keel, broadening and weakening.

The suture is simple. $E$ is as deep as and somewhat broader than $L . U_{2}$ is shallower than $\mathrm{L}$. The saddle between $\mathrm{E}$ and $\mathrm{L}$ is massive, subquadrate in rough 


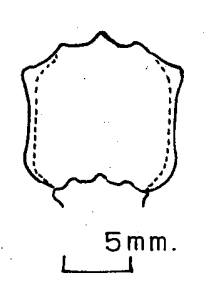

Fig. 7

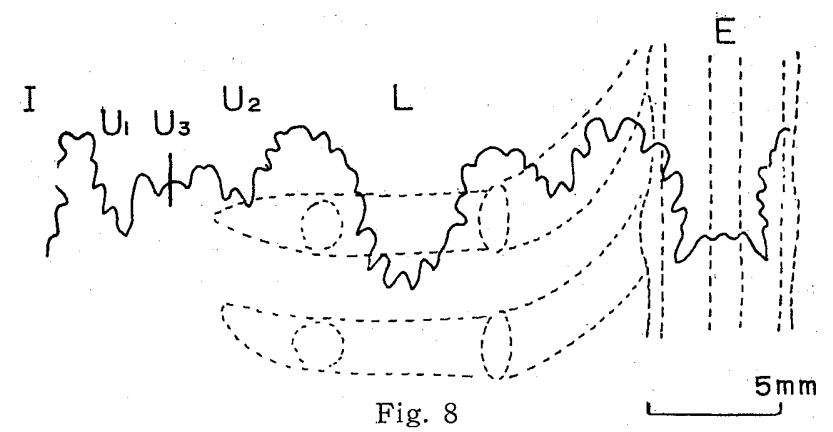

Figs. 7, 8 [47, 48]. Cobbanoceras ninakawai (YABE and SHIMIZU). Whorl-section (7) and suture (8) of the holotype, IGPS.8026, from Yanagi-no-sawa, Sanushibe, near Hobetsu, south central Hokkaido.

(T.M. delin.)

outline and shallowly bipartite. That between $\mathrm{L}$ and $\mathrm{U}_{2}$ is fairly broad and dome shaped in general outline. The saddles and lobes are not deeply incised, with only small incisions. $\mathrm{L}$ is indistinctly bipartite at the bottom.

\begin{tabular}{llcccc}
\multicolumn{2}{c}{ Measurements.- } & & & \\
Specimen & Diameter & Umbilicus & Height & Breadth & B./H. \\
IGPS. 8026 & c. $39.0(1)$ & $17.0(0.43)$ & $14.5(0.37)$ & $15.5(0.39)$ & 1.06 \\
" (*) & $34.2(1)$ & $14.7(0.43)$ & $10.6(0.31)$ & $10.8(0.31)$ & 1.02 \\
* less deformed part & & & &
\end{tabular}

Remarks.-As the specimen is wholly septate, the holotype is probably immature. To what size the adult shell of this species attains is not known.

Affinities.-YABE and SHImizu (1925, p. 138) have already pointed out that the present species has less complicated sutures than the type-species and other well-known examples of Peroniceras. The simplicity of the suture may be partly due to the immature state of the specimen, but the difference in the pattern is more than that. This species is, thus, regarded as another example of Cobbanoceras.

Compared with Cobbanoceras tanakai (p. 220 of this paper) the present species has somewhat broader whorls, less inflated flanks, and somewhat more distant and rectiradiate, instead of concave and rursiradiate, ribs.

De Grossouvre (1894, p. 94) considered that Ammonites tridorsatus SCHLŨTER. (1867, p. 26, pl. 5, fig. 1) should be included in Ammonites subtricarinatus D'ORBIGNY (1850, p. 22) [=Ammonites tricarinatus D'ORBIGNY, 1840, p. 307, pl. 91, figs. 1, 2] as a variety. He seems to have interpreted the species too comprehensively, although the European specimens need up-to-date reexamination. Anyhow, the present species resembles $A$. tridorsatus in the tricarinate venter, evolute whorls and nearly, rectiradiate, bituberculate, simple ribs. SCHLU̇TER's holotype seems to have a higher whorl, but the compression may be due to secondary deformation as in many other specimens from the Emscher Mergel. A specimen from the Coniacian of France, which was called Peroniceras subtricarinatum var. tridorsatum by Grossouvre (1894, p. 96, pl. 11, fig. 1), has a broader whorl and is very similar to the holotype of $P$. ninakawai, as YABE and SHIMIzU mentioned. The suture of the holotype, from Germany, was not described but that of an example from Italy was described by Desio (1920, p. 205, pl. 
12, fig. 10 ; text-fig. 4). The latter shows the complicated suture of Peroniceras type like that of Peroniceras subtricarinatum. Therefore it can be stated that $C$. ninakawai is well distinguished from Peroniceras tridorsatum by its simpler, less deeply incised, Cobbanoceras type suture.

In the evolute whorl, tricarinate venter and distant, rectiradiate, bituberculate ribbing Cobbanoceras ninakawai resembles Peroniceras shastense ANDERson (1958, p. 260, pl. 69, fig. 5 ; Text-fig. 9 in this paper), from California, but the latter has much broader whorls. The holotype of that Californian species is so poorly preserved that the suture is not precisely known, although it seems to be of Cobbanoceras type rather than of Peroniceras pattern. Another specimen, from almost the same loc. CIT. 1007 [=CIT. 1034] in Member IV (probably Upper Coniacian) of the Redding area, which was provisionally called Peroniceras sp. by myself (MATsumoto, 1959c, p. 123, pl. 31, fig. 6a, b; Text-fig. 10 in this paper), is closely allied to, if not identical with $P$. shastense. Its suture is simple and evidently of Cobbanoceras type. It resembles $P$. ninakawai but again has much broader whorls, with proportion of height to breadth about $1: 1.25$. The side keel of this

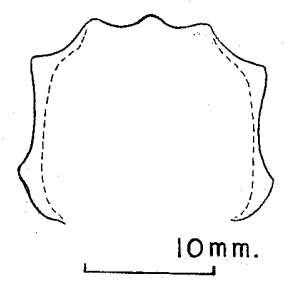

Fig. 9 , [49]. Cobbanoceras shastense (ANDERsoN). Whorl-section of the holotype, from loc. CIT. 1034, Member IV of the Redding area Cretaceous, California. (T.M. delin:)

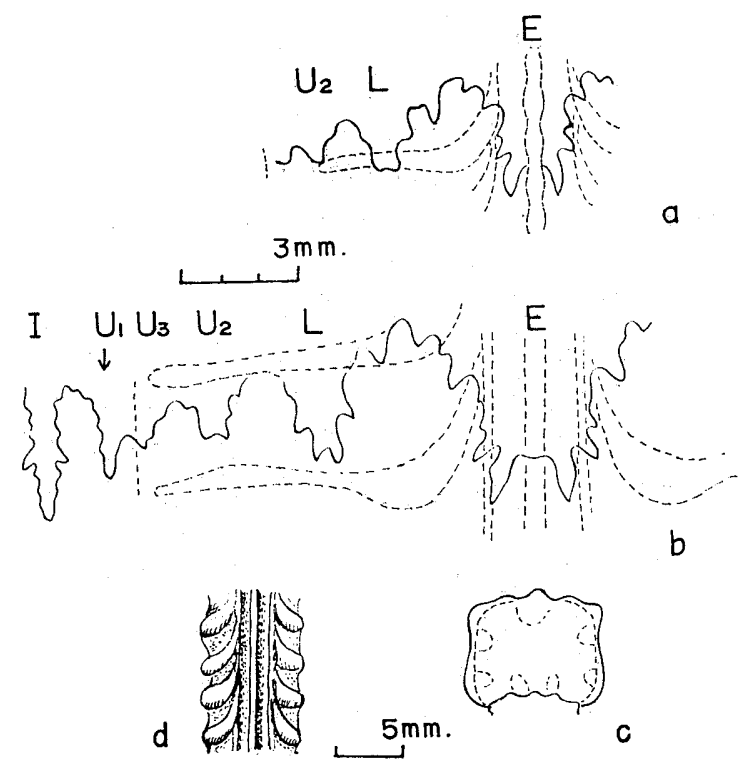

Fig. 10 [50]. Cobbanoceras sp. aff. C. shastense (ANDERSON). Sutures at diameter $=11 \mathrm{~mm}$. (a) and $19.5 \mathrm{~mm}$. (b) ; whorlsection at diameter $=28 \mathrm{~mm}$. (c); ventral view (d), at the stage a half whorl posterior to c. Specimen of UCLA. 27879, from loc. CIT. 1007, Member IV of the Redding area Cretaceous, California (see Matsumoto, 1959c, p. 123, pl. 31, fig. 6a, b).

(T. M. delin.) 
probably immature specimen is not strong and undulated owing to the joining of the projected ventral ribs. A similar feature is discernible on the inner whorl of Cobbanoceras ninakawai. This fact suggests that Cobbanoceras may have been derived from Prionocyclus.

Occurrence.--The holotype came from Yanagi-no-sawa, a branch of the Sanushibe, Iburi Province, south central Hokkaido. Zonal subdivision of the Upper Yezo Group in this part has not yet been completed, although the strata are referred to the Urakawan.

\section{Genus Sornayceras nov.}

Etymology.-Dedicated to Dr. Jacques Sornay, Institut de Paléontologie, Muséum National d'Histoire Naturelle, Paris, who has made a great contribution to our knowledge of Cretaceous palaeontology and stratigraphy.

Type-species.-Sornayceras proteus sp. nov., to be described below, from the Coniacian of Hokkaido.

Generic diagnosis.-The shell is moderately to very large. It consists of numerous more or less evolute whorls, with a wide or moderate umbilicus. The whorl is subquadrate, trapezoidal, or high subrectangular in section, with moderately inflated or flattened flanks and a low, roughly roof-shaped venter. The venter has a distinct median keel, which may be bordered by a shallow groove on either side, without distinct side keels. The median keel is entire or finely and feebly crenate.

The flanks are ornamented with radial ribs, of which some are shorter and intercalated or branched. The longer ribs are provided with umbilical tubercles, which are bullate or rounded, double or single. Each rib has a ventrolateral tubercle which is clavate or rounded. The ribs are much weakened or almost obsolete on the venter, but faint ones may be discernible between the ventrolateral tubercle and the margin of the lateral furrow.

The suture is deeply and finely incised and much complicated. The lateral lobe, $\mathrm{L}$, is very long, rather narrowed at the stem and multipartite on the sides and at the end. It is fundamentally bipartite but variously modified. The second lateral saddle is much narrowed at its stem, with deep and oblique incisions of $\mathrm{U}_{2}$ and subdivided $\mathrm{U}_{3}$. The umbilical side of this saddle and the adjoining auxiliaries form a strongly descending alinement.

Remarks.-In addition to the type-species there is another new species from Hokkaido which belongs to the present new genus. Ammonites bajuvaricus REDTENBACHER (1873, p. 107, pl. 24, fig. 2a-c; REYMENT, 1958b, p. 43, pl. 11, fig. 1a-c; text-fig. 6-3a-b), from the Gosau beds of the Alps, and Ammonites isamberti FALLot (1885, p. 232, pl. 2, fig. 1) [=? Gauthiericeras bajuvaricum of GrossouvRE, 1894, p. 88, pl. 9, fig. 1; pl. 12, figs. 2a, b, 3a, b; text-fig. 35), from the Coniacian of France, have been referred to Gauthiericeras by some authors (DE GROSSOUVRE, 1894; REYMENT, 1958b) and to Peroniceras by some others (e.g. VAN HoEPEN, 1955, p. 375). They are, however, good examples of Sornayceras defined above. GRossouvre's text-fig. 35 is too sketchy as compared with the photographed actual suture.

Ammonites propoetidum RedTEnbacher (1873, p. 116, pl. 26, fig. 6a-c; REYMENT, 
1958b, p. 41, pl. 5, fig. 1a-b ; text-fig. 2-3, 4, 4-1-3), from the Gosau beds of the Alps, should be likewise transferred from Gauthiericeras to Sornayceras. There are specimens, from Hokkaido, which should probably be referred to this species.

Peroniceras undulatocarinatum VAN HOEPEN (1955, p. 369, text-figs. 18-22), from the Coniacian of Zululand, is another example of Sornayceras, because it has a Gauthiericeras-like shell-form and Peroniceras-like sutures.

Affinities.-Sornayceras resembles Gauthiericeras in shell-form and ornamentation, but the two genera are clearly distinguished by a difference in sutures. Gauthiericeras has simple sutures, as clearly seen in the type-species, G. margae (ScHLÜTER) (see DE Grossouvre, 1894, p. 90, pl. 15, fig. 1a, b, 2a-c; text-figs. 34, 36), which are similar to those of Prionocyclus and Prionocycloceras. Sornayceras has much complicated sutures which are of the same pattern as those of Peroniceras.

Sornayceras is distinguished from Peroniceras by the lack of distinct lateral keels on the venter, although the shallow grooves on both sides of the median keel may be in some species feebly elevated along the edge. The former includes species in which the inner whorl is considerably overlapped by the outer whorl. The latter genus comprises species characterized by evolute whorls.

It is possible that Sornayceras is descended from Gauthiericeras. Species of Sornayceras seem to occur in the upper part of the Lower Urakawan in Hokkaido, approximately Upper Coniacian, but the specimens are so few that the true range is not precisely known. The succession of species from Gauthiericeras to Sornayceras through intermediate forms has not yet been confirmed by sufficient evidence.

On the other hand it should not be overlooked that in the small, inner whorls of some, if not all, species of Peroniceras only the median ventral keel is distinct and the side keels are not well developed. In other words Sornayceras resembles some species of Peroniceras in the immature stage. They may have a common ancestor, probably Prionocyclus.

Distribution.-Examples of this newly defined genus are known in the Coniacian of Japan, Europe and South Africa, and may well occur elsewhere.

Sornayceras proteus sp. nov.

P1. 40 [23], fig. 1 ; P1. 41 [24], fig. 1; Text-figs. 11 [51], 12 [52]

Etymology.-Proteus (Greek $\pi \rho \omega \tau \varepsilon v s$ ), a sea-god taking various shapes.

Material.-Holotype is GK. H5438, from Yoshiyachi-zawa, a branch of the Ikushumbets (Coll. T. Muramoto, No. 423). Another larger but fragmentary specimen, Mikasa High School Collection No. 25, is referable to the present species.

Diagnosis.-The holotype is of moderate size, but another specimen suggests that the shell of this species may have reached a large size.

The whorl enlarges rather slowly and is fairly evolute, above one third of one whorl being overlapped by the next. The umbilicus is wide, occupying about 47 percent of the entire shell diameter. The umbilical shoulder is abruptly rounded and the umbilical wall is steep and may be even overhung. The whorl is roughly trapezoidal in section, being broadest between the umbilical bullae, with somewhat inflated 

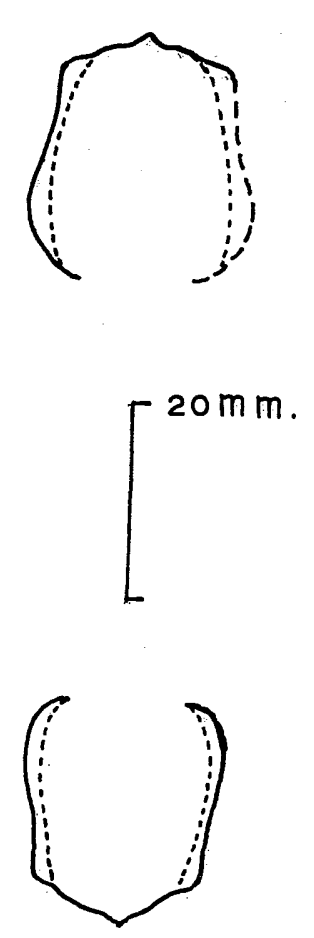

Fig. 11 [51]. Sornayceras proteus gen. et $\mathrm{sp.}$ nov. Whorl-section of the holotype, GK. H5438, from Yoshiyachi-zawa, Ikushumbets. (T.M. delin.)

flanks and a low roof-shaped, carinate venter. The outer whorl is somewhat broader than the inner, although it is still slightly higher than broad. The keel is moderately high, with a triangular cross section. It is not bordered by a distinct groove; only a very faint depression may be discernible on either side.

The flank is ornamented with distant and coarse, radial ribs and two rows of tubercles on them. Each third or fourth rib is shorter, appearing at about the middle of the flank. It is intercalated between or branched from the longer ribs. The single longer ribs are nearly rectiradiate. The other longer ribs are somewhat convex or even rursiradiate to accommodate a shorter rib in front of each of them. The shorter ribs are prorsiradiate. The umbilical tubercles are thick, bullate and highest at a short distance from the umbilical shoulder. The ventrolateral tubercles are strong and subrounded to somewhat clavate. Outward from them the ribs are broadened but much weakened, fading away before they come near the side of the ventral keel. The ribs and tubercles are somewhat coarser on the outer whorl than on the inner.

When the shell layer is well preserved, fine and feeble longitudinal (i.e. spiral) lirae may be discernible on the flank and the venter. The umbilical bullae and the ribs may be faintly crenate on crossing the lirae.

The suture is deeply and finely incised and much complicate. The ventral lobe $(\mathrm{E})$ is fairly deep and the ventral saddle occupies about a half of the depth of $E$. The lateral lobe (L) is the deepest, narrowed at the stem and multipartite, having three long folioles and two deep and narrow lobules at the bottom. Two suspensive lobes $\left(\mathbf{U}_{2}\right.$ and a subdivision of $\mathrm{U}_{3}$ ) are extremely oblique, incising deeply into the second lateral saddle. The first and the second lateral saddles are much narrowed at the stem and multipartite on the head; the latter is higher and narrower than the former. The internal suture is also deeply incised, but its details are not exposed on the available specimens.

Measurements.-

$\begin{array}{ccccccc}\text { Specimen } & \text { Diameter } & \text { Umbilicus } & \text { Height } & \text { Breadth } & \text { B./H. } & \text { U.T./V.T.* } \\ \text { GK. H5438 } & 91.0(1) & 43.3(0.47) & 25.0(0.27) & 22(?)(0.24) & 0.88 & 19 / 27 \\ \text { " } & 85.8(1) & 40.5(0.47) & 23.3(0.27) & 20.0(0.23) & 0.86 & \\ \text { MHS. 25 } & - & - & 102.5 & 48.5 \times 2 & 0.95 & \end{array}$

* U.T.=Number of umbilical tubercles per whorl

V.T.=Number of ventrolateral tubercles per whorl

Remarks.-In the holotype a part of the living chamber is preserved on the last quarter whorl. Whether the specimen represents an adult shell or is still immature is uncertain. Another larger fragmentary whorl is septate and has impression of the 


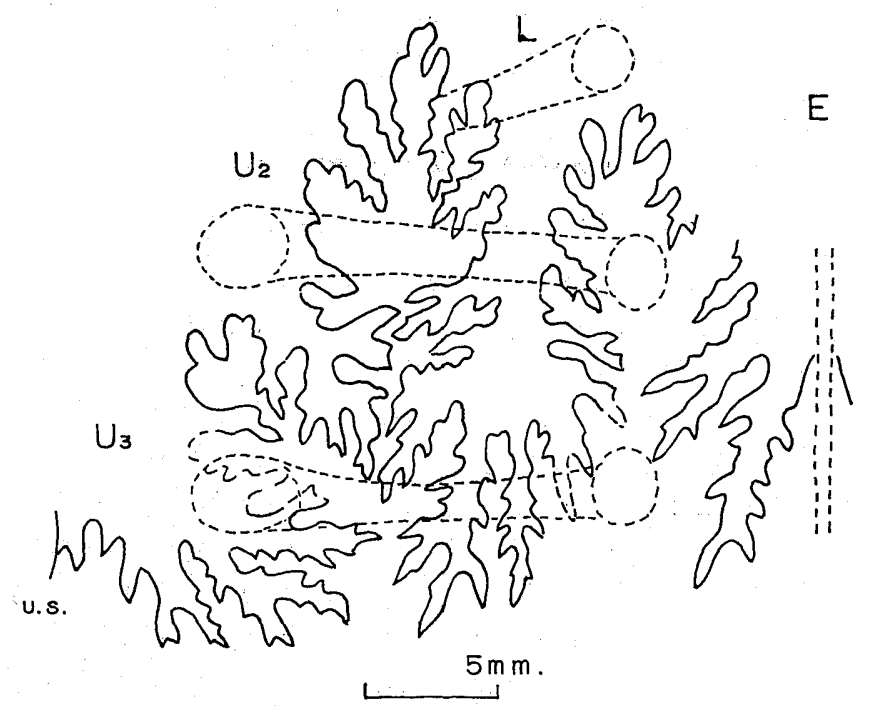

Fig. 12 [52]. Sornayceras proteus gen. et sp. nov. Suture of the holotype, GK. H5438, at whorl-height $=22 \mathrm{~mm}$. Dotted lines indicate the disposition of the keel, ribs and tubercles.

(T. M. delin.)

overlapping of still another, presumably very large whorl. It has no shorter ribs, as far as the preserved part is concerned. Otherwise it is essentially similar to the holotype. Accordingly it can be called, for the time being, Sornayceras sp. cf. S. proteus.

Affinities. - In the lateral view the present species is considerably similar to Peroniceras westphalicum (STROMBECK) (1859, p. 56, without fig.) (see ScHLU̇TER, 1867, p. 30, pl. 6, fig. 2; SchlÜTER, 1872, p. 45, pl. 13, figs. 5, 6; Grossouvre, 1894, p. 98, pl. 11, figs. 1, 4a, b, text-fig. 38; Desio, 1920, p. 214 [26], pl. 12 [1], fig. 2, pl. 13 [2], fig. 3a, b), from the Coniacian of Germany, France and Italy, in the wide umbilicus, ornamentation and pattern of sutures. $P$. westphalicum has a tricarinate and bisulcate venter and undoubtedly belongs to Peroniceras. The present species has a unicarinate venter, without or with very feeble grooves. In this respect it is similar to Gauthiericeras, but it has sutures as complicated as those of Peroniceras. P. westphalicum seems to have more compressed and evolute whorls than the present species, although the specimens from the chalk and marl of Europe may be more or less secondarily deformed.

The large specimen (Mikasa High School Coll. 25) described above (Pl. 41 [24], Fig. 1) is apparently very similar to a large specimen illustrated by Desio $(1920, \mathrm{pl}$. 13 [2], fig. 3a, b), but the latter has a tricarinate and bisulcate venter and more compressed whorls.

Occurrence.-The holotype came from Yoshiyachi-zawa, where the strata referable to upper Lower Urakawan are exposed near the confluence with the main stream of the Ikushumbets, central Hokkaido. Inoceramus cf. mihoensis occurs in the same nodule, suggesting the correctness of the age determination. The other fragmentary specimen came from the Ichi-no-sawa, a branch of the Ikushumbets. The green fine- 
sandy siltstone of the rock matrix suggests a bed in the zone of Inoceramus uwajimensis (Lower Urakawan) exposed along this stream.

Sornayceras omorii sp. nov.

P1. 42 [25], Figs. 1; 2; Text-figs. 13-15

Material.-Holotype is GK. H5493, from the upper reaches of the Ikushumbets. (Coll. Tamotsu OMorI, No. 70). Paratype is Mikasa High School Coll. No. 120, a small, probably immature shell, from the Ikushumbets.

Diagnosis.-The whorl enlarges rather slowly and fairly evolute, about one third of the inner whorl being overlapped by the outer one. The umbilicus is moderately wide, occupying 42 percent of the shell diameter in the holotype. The umbilical wall is steep but very low and the umbilical shoulder is abruptly rounded to subangular. The whorl is considerably higher than broad, with the proportion of 10:7:5 in the holotype. The flanks are flattened or only slightly inflated and nearly parallel. In the early immature stage, with a shell diameter below $20 \mathrm{~mm}$., they are slightly divergent and the whorl is broadest between the ventrolateral shoulders. The venter is roof-shaped; the ventrolateral shoulder is sloping in intercostal section and subangular in costal section.

The keel on the top of the venter is rather narrow but sharp, triangular in cross. section, and is bordered on either side by a very shallow and rather narrow groove. The other edge of the groove may look slightly elevated, but the elevation, if present, is not distinct enough to be called a side keel.

The flank is ornamented with low and moderately broad, radial ribs, rather weak umbilical tubercles and ventrolateral tubercles of moderate size and intensity. The

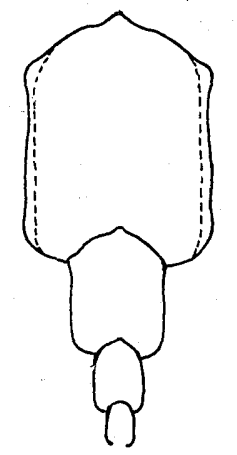

$10 \mathrm{~mm}$.

Fig. 13 [53]. Sornay. ceras omorii gen. et $\mathrm{sp}$. nov. Cross section of the holotype, GK. H5493, from the Ikushumbets, central Hokkaido.

(T.M. delin.) ribs are separated by interspaces as broad as or slightly broader than the ribs themselves. Many of the ribs are long and single, but every second or third long rib has a branched or intercalated shorter one behind it. Some of the longer ribs are gently convex, with gently prorsiradiate inner half and slightly rursiradiate outer half. Some other longer ribs are nearly rectiradiate or slightly prorsiradiate. The shorter ribs are more or less rursiradiate. While the outer half of the rib below the ventrolateral tubercle is lowered, the inner half is somewhat thickened, forming an umbilical bulla. Occassionally the outer end of the thickened part of the rib is slightly elevated, if not so distinctly high as to be called a lateral tubercle. This gives rise, combined with the elevation of the inner end of the rib, to an indistinct doubling of the umbilical bulla. The ventrolateral tubercles are rounded or somewhat clavate. From the tubercles the ribs run forward with much weakening and broadening on the venter, fading away before they reach the edge of the 
groove. On the well preserved surface of the flanks and ventrolateral parts numerous. longitudinal (i. e. spiral) lirae may be discernible which give rise to faint crenation on crossing the ribs.

The suture is deeply and finely incised and very complicated. The first lateral saddle is asymmetrically divided by a fairly deep lobule; ventral branch being narrower than the ventrolateral one. The lateral lobe $(\mathrm{L})$ is the longest; it is narrow at the stem but expanded and deeply incised on the sides and at the bottom. The second lateral saddle (inside of $\mathrm{L}$ ), which is more or less higher than the first, has an expanded and multipartite head and an extremely narrow stem, with deep incisions of $U_{2}$, branches of $\mathrm{L}$ and $\mathrm{U}_{3}$. The auxiliaries $\left(\mathrm{U}_{2}\right.$ and subdivided $\left.\mathrm{U}_{3}\right)$ are obliquely arranged, resulting in a strongly descending alinement from the top of the second lateral saddle. towards the umbilical seam.

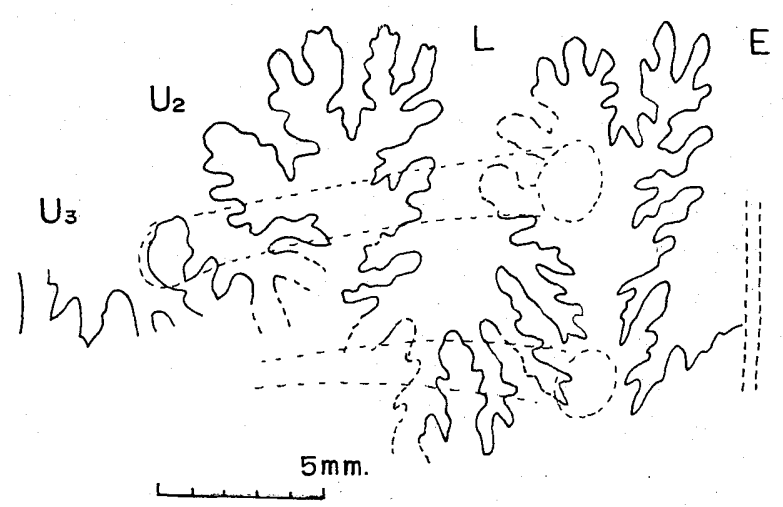

Fig. 14 [54]. Sornayceras omorii gen. et sp. nov. Suture of the holotype, GK. H5493, from the Ikushumbets, at whorlheight $=17 \mathrm{~mm}$.

(T.M. delin.)

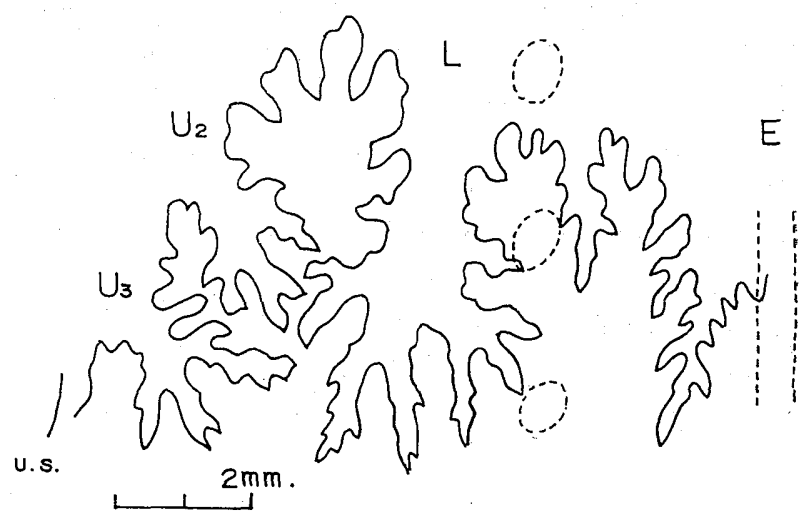

Fig. 15 [55]. Sornayceras omorii gen. et sp. nov. Suture of a paratype, MHS. 120, from Ikushumbets, central Hokkaido.

(T.M. delin.) 


\begin{tabular}{|c|c|c|c|c|c|c|}
\hline Specimen & Diameter & Umbilicus & Height & Breadth & B. $/ \mathrm{H}$. & U.T./V.T.* \\
\hline GK. H5493 & $55.0(1)$ & $23.1(0.42)$ & $19.8(0.36)$ & $14.5(0.26)$ & 0.74 & $23 / 34$ \\
\hline$"(-1$ vol. $)$ & $26.4(1)$ & $10.2(0.39)$ & $9.0(0.34)$ & $6.5(0.25)$ & 0.72 & - \\
\hline MHS. 120 & - & - & 9.2 & 7.0 & 0.76 & $6 / 9 * *$ \\
\hline
\end{tabular}

Remarks.-The holotype is wholly septate, but in association with it there is a displaced fragment of an unseptate whorl, which is probably the body-whorl of the same individual. The paratype is fragmentary but agrees well in many characters with the inner whorls of the holotype. The suture is better exposed on the paratype.

Affinities.-The present species is closely allied to Ammonites bajuvaricus REDTENBACHER (1873, p. 107, pl. 24, fig. 2a-c) (lectotype as designated and reillustrated by Reyment, 1958, p. 43, pl. 11, fig. 1a-c; text-fig. 6-3a-b), from the Alpine Gosau beds, but the former has not so numerous and so crowded ribs as the latter. The whorl enlarges more slowly and the umbilicus is wider in the former than in the latter. REDTENBACHER's measurements show that the umbilicus of the Alpine specimen is only 31 percent of the diameter. If the illustration of the suture by REDTENBACHER is right, as REYMENT admits, it follows that the difference in suture between the two species is considerable. I doubt, however, the accuracy of the drawing, because it does not seem to agree very well with the photograph. The deeply incised complex suture, with a narrowed stem of the second lateral saddle and descending auxiliaries, indicates that Ammonites bajuvaricus should be better referred to Sornayceras rather than to Gauthiericeras.

De Grossouvre (1894, p. 88, pl. 9, fig. 1; pl. 12, figs. 2a, b, 3a, b; text-fig. 35) assigned Ammonites bajuvaricus ReDtenBACHER, 1873, to Gauthiericeras, a genus established by himself; and regarded Ammonites isamberti FALLOT (1885, p. 232, p1. 2, fig. 1) as a synonym of $A$. bajuvaricus. Although I have had no opportunities to examine the actual specimens from the Alps, I doubt the identity of the French specimens with the lectotype from the Alps. The specimens from the Coniacian of France, as described by FALLOT and DE GROSSOUVRE, seem to represent a species which can be distinguished from Sornayceras bajuvaricum by the slower enlargement of whorls, wider umbilicus and less numerous ribs. One of GROssouvRE's specimen (1894, pl. 12, fig. 3) may show an intermediate state as regards the growth of whorls and width of umbilicus, but it has evidently less numerous and less crowded ribs than the lectotype of $S$. bajuvaricum.

It is also doubtful whether GRossouvRE's specimens are identical with FALLOT's or not, seeing that in the former the umbilicus is not so widely opened and the ventrolateral tubercles are not so clavate as in the latter. For the time being I would call FALLOT's specimen S. isamberti (FALLOT) and GROSSOUVRE's specimens S. aff. isamberti (FALLOT). In the above mentioned respects the new species from Hokkaido is more closely allied to this $S$. aff. isamberti than to $S$. bajuvaricum. In the French species, however, the umbilical tubercles are more distinct than ours and the tendency of doubling of the umbilical bullae as seen in the Japanese species does not occur at 
all. Anyhow, the resemblance is so remarkable that it could be considered that the separation of the two groups of specimens between Japan and France is only subspecific. This should be examined by further study of more numerous specimens.

Incidentally the specimen described as Schloenbachia (Gauthiericeras) bajuvarica by Boule, Lemorne and Thevenin (1907, p. 22 [42], pl. 5 [12], fig. 1, 1a; text-fig. 22), from Madagascar, is, in my opinion, a species of Prionocycloceras, close to the one from Hokkaido which I described in Part I as Prionocycloceras sp. aff. P. lenti (GERHARDT) (MAtsumoto, 1965, p. 45, pl. 11, figs. 2, 3).

Occurrence.-The holotype came from a locality on the main upper stream of the Ikushumbets, somewhat above the mouth of a tributary, Inari-zawa, Ishikari Province, central Hokkaido. It was preserved in a calcareous nodule, along with Damesites damesi and Inoceramus cf. yokoyamai, embedded in siltstone of the middle part of the Upper Yezo Group, probably referable to the upper part of Lower Urakawan, i.e. approximately Upper Coniacian. The paratype was collected by a schoolboy from Mikasa High School from the Ikushumbets, without a precise locality record.

The allied species S. aff. isamberti occurs in Touraine, France, at the base of "la craie de Villedieu," that is, according to LECOINTRE (in SoRnAY et al., 1957, p. 380), Lower Coniacian.

\section{Sornayceras sp. cf. S. propoetidum (REDTENBACHER)}

Compare.P1. 39 [22], Figs. 2, 3; Text-fig. 16 [56]

1873. Ammonites propoetidum Redtenbacher, Abh. k. k. geol. Reichsanst., Wien, vol. 5, no. 5, p. 116, pl. 26, fig. 6a-c.

1935. Prionotropis propoetida, Brinkmann, Mittle. geol. Staatsinst. Hamburg, no. 15, p. 3.

1958. Gauthiericeras propoetidum, Reyment, Stockholm Contr. Geol., vol. 2, no. 3, p. 41, pl. 5, fig. 1a-b; text-figs. $2-3,4,4-1-3$.

Material.-Two small, imperfectly preserved specimens, Mikasa High School Collection No. 122 and No. 123.
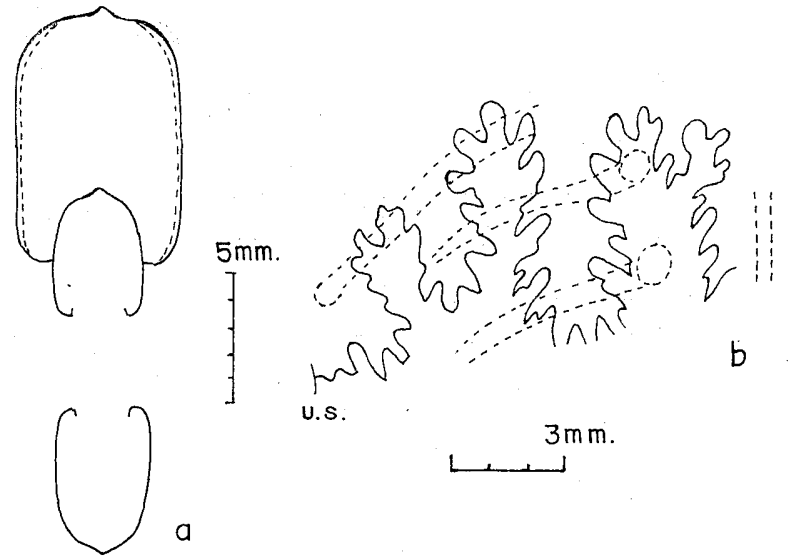

Fig. 16 [56]. Sornayceras sp. cf. S. propoetidum (Redtenbacher). Whorlsection (a) and suture (at whorl-height $=9.5 \mathrm{~mm}$.) (b) of a specimen, MHS. 122, from the Ikushumbets, central Hokkaido.

(T.M. delin.) 
Description.-The two specimens show the following characteristic features. The whorl enlarges rather rapidly, with a moderate involution. The umbilicus is comparatively narrow, occupying slightly less than 30 percent of the diameter. It is very shallow, bordered by a low, vertical wall and abruptly rounded umbilical shoulder. The whorl is compressed, with flat and nearly parallel flanks. The proportion of whorl height to breadth is about $10: 6$ to 7 . The ventrolateral shoulder is sloping. The venter is arched, rather narrow, and provided with a finely and weakly crenate median keel, bordered on either side by a very shallow and narrow furrow. The other edge of the furrow is faintly elevated, but on the inner whorl the elevation is hardly discernible.

The numerous ribs on the flank are somewhat prorsiradiate and many of them are bifurcated at or near the umbilical bullae. A few of them are single. Some ribs are gently flexuous. The umbilical tubercles are most prominent at the shoulder and are extended radially. The ribs are elevated gradually to the ventrolateral tubercles, which are of moderate intensity and some of which are clavate on top. On the venter the ribs are weakened, broadened and bent forward and in addition to them intercalated short riblets may be seen. The crenations on the keel are almost twice as numerous as the ventrolateral tubercles. The umbilical tubercles seem to be slightly more than a half as numerous as the ventrolateral ones. In a quarter whorl of MHS. 122, 9 ventrolateral tubercles and 5 umbilical tubercles are seen. The inner whorl, below a diameter of $14 \mathrm{~mm}$., has nearly smooth flanks.

In spite of the small, probably immature state of the shell, the suture is rather deeply incised. The lateral lobe is the longest, comparatively narrow and deeply incised by several, narrow, folioles. The first lateral saddle (between $\mathrm{E}$ and $\mathrm{L}$ ) is higher than broad but is not much narrowed. The second lateral saddle (between $\mathrm{L}$ and $\mathrm{U}_{2}$ ) is much higher than broad and is considerably narrowed at the stem. The auxiliaries are remarkably descending, with slightly oblique $U_{2}$ and much oblique subdivision of $\mathrm{U}_{3}$.

$\begin{array}{lccccc}\text { Measurements. } & & & & & \\ \text { Specimen } & \text { Diameter } & \text { Umbilicus } & \text { Height } & \text { Breadth } & \text { B./H. } \\ \text { MHS. } 122 & 20.5(1) & 5.5(0.27) & 9.5(0.46) & 6.3(0.30) & 0.66 \\ \text { " (+1/4 vol.) } & - & - & 11.5 & 7.2 & 0.62 \\ \text { MHS. } 123 & - & - & 12.9 & 9.2 & 0.69\end{array}$

Comparison.-In almost all the characters described above the two specimens from Hokkaido are closely allied to and probably to be identified with the holotype of $\mathrm{Am}$ monites propoetidum REDTENBACHER, 1873 (photographically reillustrated by REYMENT, 1958b, pl. 5, fig. 1a-b), from the Coniacian part of the Gosau beds of the Alps. Unfortunately the holotype of REDTENBACHER's species is secondarily deformed and our specimens are also imperfectly preserved. Therefore I hesitate to give a definite conclusion of specific identity.

Ammonites propoetidum was ascribed to Gauthiericeras by REYMENT (1958, p. 41), but its deeply incised suture is dissimilar to the much simple suture of the type-species, G. margae (SCHLÜTER), and other unmistakable examples of Gauthiericeras. In this and other respects this species is a good example of Sornayceras. 
It may be interesting to note that $S$. propoetidum resembles to some extent Prionocycloceras lenti (GERHARDT) (1897, p. 77, pl. 1, fig. 4a, b; text-fig. 3; REYMENT, 1958a, p. 12, pl. 3, fig. 1a, b; text-fig. 4b) (see also Part I of this monograph, p. 45). In that species there is no sign of side keels, its median ventral keel is distinctly crossed by projected ventral ribs, riblets and striae, its venter is more gently arched or flatter, its ventrolateral shoulder is more distinct and the suture is simpler, following the pattern of Prionocyclus. The resemblance is not, in my opinion, sufficient for justify these species as transition between Prionocycloceras and Gauthiericeras, as SPATH (1926, p. 80) at one time held.

Occurence.-One of the specimens, MHS. No. 122, came from a locality on the Ikushumbets, somewhat above the confluence with the Inari-zawa, close to the typelocality of Sornayceras omorii. It was found in a calcareous nodule of sandy siltstone, belonging probably to the upper part of the Lower Urakawan (approximately Upper Coniacian), in the Upper Yezo Group. The other specimen, MHS. No. 123, was obtained as a pebble of calcareous nodule in a stream of Yoshiyachi-zawa, a branch of the Ikushumbets. In the same stream the holotype of Sornayceras proteus was also obtained.

\section{Genus Ishikariceras nov.}

Etymology.-Taken from the celebrated Ishikari Province, central Hokkaido, where a great number of ammonites, including the present genus, have been obtained by various investigators.

Type-species.-Ishikariceras binodosum sp. nov., to be described below.

Generic diagnosis.-The shell is moderate in size. The whorl is evolute, with an widely open umbilicus. The whorl section is subquadrate in the immature stages and semi-elliptical in the adult. The venter has a median keel bordered by shallow grooves. The side keels are almost undiscernible or very weak, if existent.

The inner whorls are ornamented with low, rectiradiate, rather distant, mostly single ribs, each of which is provided with an umbilical and a prominent ventrolateral tubercle. On the outer whorl the ribs and tubercles disappear almost completely, but very shallow constrictions may be developed.

The suture is rather simple. The first lateral saddle is massive, subquadrate in rough outline, asymmetrically bifurcate. The lateral lobe $(\mathrm{L})$ is longer than broad but its stem is not so narrow as in that of Peroniceras and its minor incisions are simple and not very deep. The second lateral saddle is higher than broad but is not so much narrowed as that of Peroniceras. The auxiliaries are only slightly oblique and does not form a strongly descending alinement.

Remarks.--In addition to the type-species Schloenbachia schneeblii Boule, LEMOINE and Thevenin (1907, p. 17 [37], pl. 5 [12], fig. 2, 2a; text-fig. 20), from the Senonian of Madagascar, is to be referred to this genus.

Affinities.-With respect to the characters of the inner whorl the proposed new genus considerably resembles Gauthiericeras (Ciryella) WIEDMANN, 1959, from the Lower Coniacian of Spain, but in the former the tubercles are predominant over ribs and are sometimes mammillate and the ribs are mostly single. While the ornament 
persists to the outer whorl in Gauthiericeras (Ciryella), as well as in Peroniceras, it disappears almost completely in the outer whorl of Ishikariceras, which has a semielliptical section, with loss of angular ventrolateral shoulders.

In the sudden change of ornament and shell-form and in the general aspects of the shell Ishikariceras is apparently similar to Yabeiceras TokUNAGA and SHIMIZU, 1926, from the Coniacian of Japan and Madagascar. As has been recently described in detail (MATSUmoto, OBATA, MAEdA and SATo, 1964), the inner whorls of Yabeiceras have characters which are closely allied to Forresteria REESIDE, 1931, of the subfamily Barroisiceratinae. They are, therefore, distinct from the inner whorls of the present genus. There is also a considerable difference in the pattern of suture. Thus the resemblance of the two genera are rather superficial and homoeomorphic.

Distribution.-The type-species is from the Lower Urakawan (Coniacian) of Hokkaido. Another species is from the Senonian of Madagascar. They are rare in occurrence. According to Dr. VAN HoEPEN's reply to my inquiry, there is in South Africa a Peroniceras-like species which has a smoothish outer whorl. This might be another example of Ishikariceras, although I do not know the details.

In view of the long distance between Japan and Madagascar or South Africa, the genus must have been fairly widely distributed.

Ishikariceras binodosum sp. nov.

$$
\text { Pl. } 43 \text { [26], Fig. 1; Text-figs. } 17 \text { [57], } 18 \text { [58] }
$$

Material.-Holotype is a specimen, GK. H5576, from the upper reaches of the Ichi-no-sawa, a branch of the Ikushumbets, where unit IIIb of the Upper Yezo Group is well exposed. It is partly broken and deformed but is well characterized.

Diagnosis.-The shell is moderate in size, about $120 \mathrm{~mm}$. in diameter of the restored figure of the holotype, consisting of rather slowly enlarging, evolute whorls. The outer whorl overlaps only the low ventral part of the inner whorl. The umbilicus is widely open, occupying nearly 50 percent of the shell diameter.

The inner whorl is subquadrate in section, slightly broader than high, and has parallel flanks. Its venter is broadly arched and is provided with a fairly broad, round topped, median keel bordered on either side by a shallow, weak groove. Its flank is ornamented with distant, nearly rectiradiate, single ribs, each of which has a moderately strong umbilical and a very strong ventrolateral tubercle. As the ribs are low and weak, the tubercles are predominant over ribs. They are rather mammillate or spinose on the whorl with diameters from 25 to $40 \mathrm{~mm}$., beyond which the umbilical tubercles are weakened and bullate. The highest point of the umbilical tubercle is somewhat above the umbilical shoulder.

The outer whorl is semi-elliptical in section, somewhat higher than broad, having a rounded venter which passes gradually to the flanks without angular ventrolateral shoulders. The median ventral keel persists, with accompanying very shallow furrows, although it is weakened. A faint demarcation can be seen on the outer side of the furrow, but this is not elevated enough to be called a side keel. The characteristic ornament as seen on the inner whorls disappears and the outer whorl is almost 
smooth. Only faint lirae and shallow, incomplete constriction-like depressions may be discernible under oblique lighting. They show a concave curvature and are somewhat prorsiradiate.

The suture, as seen on an inner whorl, is comparatively simple. The ventral lobe $(\mathrm{E})$ is fairly broad and deep. The first lateral saddle, between $\mathrm{E}$ and $\mathrm{L}$, is massive, squarish in a rough outline, and asymmetrically bipartite, with a moderately deep and narrow lobule immediately outside the ventrolateral tubercle. The lateral lobe $(\mathrm{L})$ is long but fairly broad, without showing constriction of its stem. Its bottom is bipartite, but the lobules and the median foliole are small. The branches on its sides are also small and not deep. The second lateral saddle, between $\mathrm{L}$ and $\mathrm{U}_{2}$, is slightly lower than the first and moderately broad. Its head is asymmetrically roundish in a rough outline and is incised by small, rather shallow lobules. Its sides are also incised by several lobules, but the lobules are not deep enough to make the stem of the saddle narrow or constricted. The lobe $\mathrm{U}_{2}$, inside of the second lateral saddle, is slightly oblique, about half as short and narrow as L. Other auxiliaries are small and not numerous. The internal suture is unexposed.

\section{Measurements.-

$\begin{array}{cccc}\text { Specimen } & \text { Diameter } & \text { Umbilicus } & \text { Height } \\ \text { K. H5576 } & c .120(1) & 60(0.50) & 33.5(0.28) \\ " \text { (-1 vol.) } & - & - & 18.0\end{array}$

Affinities.-The present new species is very close to Schloenbachia schneeblii BoulE, Lemoine and Thevenin (1907, p. 17 [37], pl. 5 [12], fig. 2, 2a), from the Senonian of the Montagne de Francais (Diego-Suarez), northern Madagascar, in its Peroniceras- or Gauthiericeras (Ciryella)-like inner whorls and the smoothish outer whorl. The Madagascar species is, in my opinion, better assigned to Ishikariceras than to any other

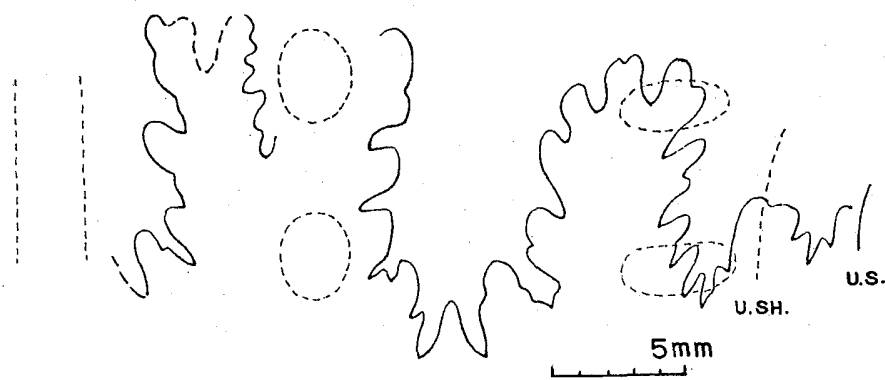

Fig. 18 [58]. Ishikariceras binodosum gen. et sp. nov. Suture, at whorl-height $=17 \mathrm{~mm}$., of the holotype, GK. H5576, from Ichi-no-sawa, Ikushumbets, central Hokkaido.

(T. M. delin.) 
genera. The distinction between it and our species is sufficient to separate them specifically. As has been described by Boule et al., there are low side keels in the Madagascar species, while in ours they can be said to be undeveloped. The umbilical tubercles on the inner whorls are more prominent in the Japanese species. Another, clearer distinction is in the pattern of the suture. P. schneebli has a considerably deep lobule at the bottom of the lateral lobe, which is, accordingly tripartite. Boule et al. (1907) described the suture of $P$. schneebli as of the hoplitid type. On the other hand, the lateral lobe in $P$. binodosum is bipartite at the bottom. The difference is probably no more than specific, seeing that other examples of the Peroniceratinae show a considerable variability as regards the details in the mode of branching of the lateral lobe (see, for instance, REYMENT, 1958b).

In the unicarinate venter the present species is somewhat allied to Gauthiericeras (Ciryella) vascogoticum Wiedmann, 1959, from the Lower Coniacian of Spain, but the keel is broader and more rounded in the former. On the inner whorls the former has mostly single, more distant ribs and stronger tubercles as compared with frequently appearing shorter, bifurcated or intercalated ribs and moderate tubercles of the latter. The difference in the outer whorl is remarkable between the two species.

In the evolute whorls, apparently unicarinate venter, mammillate tubercles on the inner whorl and smoothing of ornaments on the outer whorl the present species is apparently similar to Yabeiceras orientale ToKunAGA and SHIMIzU, 1926, from the Coniacian of the Futaba area and Hokkaido. The similarity is superficial, because $Y$. orientale has characters which are closely related to Forresteria, as has been recently made clear by MATsumoto et al. (1964).

To sum up, Ishikariceras binodosum was probably derived from a species of Gauthiericeras (Ciryella) and is genetically unrelated with Yabeiceras orientale.

Occurrence.-The holotype was obtained by Mr. Katsuaki TomiokA, a schoolboy from Mikasa High School, on Sept. 15, 1959, from a nodule in sandy siltstone exposed at a point $4.5 \mathrm{~km}$. from the entrance (along an abandoned forestry railway) in the upper reaches of the Ichi-no-sawa, a tributary of the Ikushumbets, Ishikari Province, central Hokkaido. The bed belongs to the zone of Inoceramus uwajimensis, Lower Urakawan (Coniacian).

\section{Genus Reymentites nov.}

Etymology.-Dedicated to Professor Dr. Richard A. REYMENT who has made a great contribution to our knowledge of the Mesozoic Ammonoidea. This generic name is obviously distinct from Reymentoceras WIEDMANN, 1959.

Type-species.-Reymentites hataii sp. nov., to be described below.

Generic diagnosis.- The whorl is fairly evolute, with a moderately wide umbilicus. It is subquadrate to subrectangular in section. The venter of the outer whorl is distinctly tricarinate and bisulcate; that of the inner whorl is normally tricarinate but the side keel may be wavy.

The flank is ornamented with radial ribs which are mostly single. Each rib has an umbilical, one or two lateral and a ventrolateral tubercles. The lateral tubercles are incipient and weak in an immature stage, comparatively distinct in the adolescent 
stage and again may become indistinct or absorbed by the ribs in the adult or senile (?) stage. From the ventrolateral tubercles the ribs are somewhat projected, broadened and lowered, ending at the side keel. On the inner whorl the ends of these ventrolateral ribs form clavate elevations, giving rise to a wavy, incipient, side keel.

The suture is of normal collignoniceratid type, resembling that of Prionocyclus or Texanites.

Remarks.-I think it better to transfer Reginaites durhami Young, 1963 to Reymentites for the reasons to be discussed below.

Affinities.-Reymentites resembles Reginaites REYMENT, 1957, in the evolute whorls, tricarinate venter, presence of three or four tubercles and normal collignoniceratid sutures. In the former the three or four tubercles are nearly equidistant and no two of them are approximated, while in the latter the two ventrolateral tubercles are approximated and are much apart from the umbilical tubercles. In the latter a row of lateral tubercles is developed only on the outer whorl, as in Reginaites quadrituberculatus REYMENT (1957, p. 65, pl. 11, fig. 1a, b; text-fig. 7) and in Reginaites leei (REESIDE) (1927, p. 40, pl. 42, figs. 1, 2 ; pl. 43, figs. 3, 4).

The above statement implies that Reymentites is intimately related with Protexanites Matsumoto, 1955, or with Texanites SpATH, 1931, and that Reginaites is closely allied to Paratexanites Collignon, 1948.

Reymentites resembles Cobbanoceras, a new genus described in page 219, in many respects, but is distinguished by the development of lateral tubercles.

Reymentites is apparently similar to Peroniceras DE GRossouvre, 1894 (redefined in page 212), in the tricarinate venter and rather evolute whorls, but is well separable in that the latter has much complicated and specialized sutures and no lateral tubercles. The same can be said of the relation between Reginaites and Peroniceras. Consequently I would regard Reginaites (as well as Reymentites) as generically distinct from Peroniceras, although REYMENT (1957, p. 65) proposed Reginaites as a subgenus of Peroniceras.

The wavy side keel on the inner whorl of the type-species of Reymentites could be considered as being related to and possibly led from a train of the ventral clavi of Protexanites or Texanites. A similar feature is seen on the inner whorl of Cobbanoceras (see page 219).

While the well defined species of true Peroniceras occur in the Coniacian (mostly Lower Coniacian), those of Cobbanoceras in the Santonian and Upper Coniacian. Paratexanites and Protexanites are Coniacian to Santonian genera. As Young has pointed out, species of Reginaites seem to occur rather in the Santonian or Lower Campanian, although REYMENT referred the type-species to Upper Coniacian. Reymentites probably shows almost the same stratigraphical range as Reginaites.

On the grounds of all the above discussed morphological relations and also for the available evidence of stratigraphic occurrence, I am rather inclined to think that Cobbanoceras, Reymentites and Reginaites could be regarded as Peroniceras-like tricarinate derivatives from Protexanites (trituberculate earlier subgroup), Protexanites (quadrituberculate later subgroup) or Texanites, and Paratexanites respectively. Whether Reymentites was derived from Cobbanoceras by addition of lateral tubercles 
or straight from Protexanites or Texanites by smoothing of a continuous train of ventral clavi is not decided here. Gauthiericeras, Sornayceras, Peroniceras and Ishikariceras can better be taken as descendants from Prionocyclus rather than from Subprionocyclus, as has been explained in the descriptions of the respective genera. Therefore, if the above presumption was warranted, the Peroniceratinae would be polyphyletic.

On the other hand it is possible that Reymentites originated in Prionocyclus. Later species of Prionocyclus, such as P. reesidei Sidwell, 1932, and P. quadratus COBBAN, 1953, have incipient, faint lateral tubercles on the outer whorl. These could have developed into the more distinct lateral tubercles of Reymentites. In these species of Prionocyclus the edge of the shallow groove on either side of the siphonal keel is slightly elevated where the projected ventral ribs adjoin. This could have led to the side keel of Reymentites. In fact the inner whorl of Reymentites has a weak, gently undulated side keel resembling the slight elevation at the edge of the groove in some Prionocyclus. A similar feature is observable on the inner whorl of a certain species of Cobbanoceras, as explained in page 220. I have not yet confirmed this point concerning the inner whorl of Reginaites.

Anyhow, the available lines of evidence are by no means sufficient to decide finally one of the two alternatives. For the time being I am describing Reymentites under the subfamily Peroniceratinae, although it might be possible to group Reymentites, Reginaites and also Cobbanoceras into a new subfamily.

Distribution.-The type-species occur in the Urakawan of Hokkaido. Another species, Reymentites durhami Young, was recorded to occur at the base of Campanian in Texas. The occurrence is rare in both cases. Further collecting is necessary to make clear the true stratigraphic range and the geographic distribution of Reymentites.

Reymentites hataii sp. nov.

P1. 42 [25], Fig. 3 ; Text-figs. 19 [59], 20 [60]

Material.--The holotype, IGPS. 54746, from the Ikushumbets, is the sole representative of the present species. I had an opportunity of studying this interesting specimen in the collection of Tohoku University by courtesy of Professor Kotora HATAI, to whom the specific name is dedicated.

Diagnosis.--The whorl enlarges rather slowly, embracing an umbilicus of moderate width which is about 44 percent of the shell diameter. It is subquadrate in costal section, which is almost as high as broad, with subangular umbilical and ventrolateral shoulders. The venter is distinctly tricarinate and bisulcate on the outer whorl. The median keel is more prominent than the lateral ones and they are fairly close to each other. The slope between the lateral keel and the ventrolateral angle inclines considerably and, accordingly the venter is roughly roof-shaped. The side keel is narrow, continuous and smooth on the outer whorl, but it is wavy and apparently discontinuous on the inner whorls.

The ribs on the flank are single, about 14 on the outer half whorl and 11 on the inner half of the holotype, being separated by somewhat wider interspaces. They 
are nearly rectiradiate or slightly prorsiradiate around the umbilical margin and then bent more distinctly forward on the ventrolateral part.

The end of the rib at the umbilical shoulder sometimes looks slightly elevated but is not so pointed as to be called a distinct tubercle. The unmistakably distinct tubercle is at a point somewhat above the umbilical shoulder. Another distinct and larger tubercle is at the ventrolateral shoulder, which is clavate at the top. In addition to the two prominent tubercles there is a weaker, smaller tubercle at the upper lateral point slightly above the midpoint between them.

From the ventrolateral clavus the rib is bent forward, with broadening, and ends at the side keel. On the inner whorl a clavate, narrow elevation is seen at the end of the projected ventral rib, giving rise to an undulatory, apparently less continuous side keel.

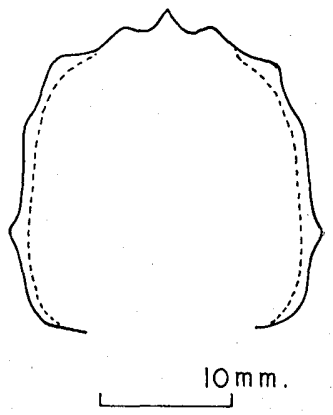

Fig. 19 [59]. Reymentites hataii gen. et sp. nov. Whorl-section of the holotype, IGPS. 54746 , from the Ikushumbets, central Hokkaido.

(T. M. delin.)

The suture is of general collignoniceratid type, resembling that of Collignoniceras or Texanites. The ventral lobe $(\mathrm{E})$ is deep and broad. The first lateral saddle between $\mathrm{E}$ and $\mathrm{L}$ is very broad, massive, subquadrate to dome like in a rough outline and asymmetrically bipartite by a moderately deep lobule, resulting in a larger, multipartite, outer and a narrower inner branch. The lobule is immediately inside the row of ventrolateral clavi and the inner branch is on the row of upper lateral tubercles. The lateral lobe (L) is the deepest of all, longer than broad, but not much narrowed at the stem. It is elongated $U$-shaped or $\mathrm{V}$-shaped in rough outline and has several minor, simple lobules on both sides. It is bipartite. The second lateral saddle is nearly as high as and about a half as narrow as the first. It is asymmetric in shape and is on the row of the umbilical (i. e. actually lower lateral) tubercles. The next lobe $\mathrm{U}_{2}$ is nearly a half as shallow and narrow as $\mathrm{L}$; it is not much oblique, extending across the umbilical bulla immediately above the umbilical shoulder. The minor saddle inside $\mathrm{U}_{2}$ is nearly as high as the second lateral saddle and, thus, the auxiliaries form a roughly radial alinement, and is not descending.

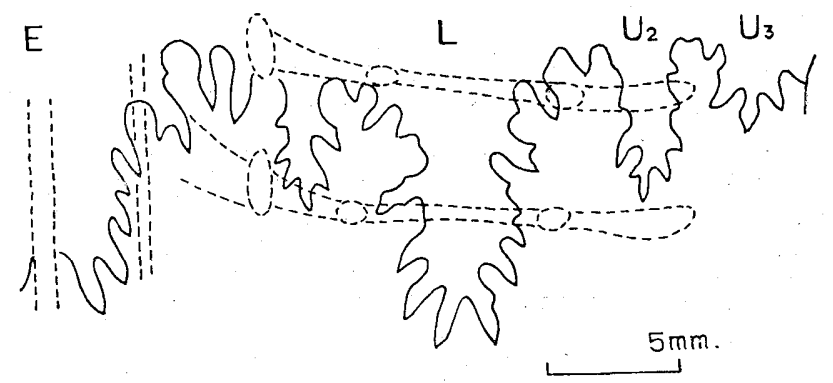

Fig. 20 [60]. Reymentites hataii gen. et sp. nov. Suture, at whorl-height $=25 \mathrm{~mm}$., of the holotype, IGPS. 54746, from the Ikushumbets, central Hokkaido.

(T.M. delin.) 


\begin{tabular}{lllccc}
\multicolumn{2}{c}{ Measurements.- } & & & & \\
$\quad$ Specimen & Diameter & Umbilicus & Height & Breadth (costal) & B./H. \\
IGPS. 54746 & $69.5(1)$ & $30.4(0.44)$ & $25.0(0.36)$ & $23.8(0.34)$ & 0.95 \\
" $(-1 / 2$ vol. $)$ & $48.5(1)$ & $21.0(0.44)$ & $16.2(0.34)$ & $15.8(0.32)$ & 0.97
\end{tabular}

Remarks.-The described specimen had a label on which the specific name was written by someone as Peroniceras ninakawai YABE and SHIMIzU, but this is not the original type of that species and has not been described.

Affinities.--The present species indeed resembles Cobbanoceras ninakawai (YABE and SHImizu, 1925), redescribed in this paper (p. 223), but is distinguished by the development of the upper lateral tubercles on the outer whorl. The ribs are rather prorsiradiate in the former, but they are rectiradiate in the latter. The exposed suture is somewhat simpler in the latter than in the former, but this may be due to the difference in growth-stage.

Reymentites hataii is fairly similar to Reymentites durhami (Young) (1963, p. 92, pl. 39, fig. 2 ; pl. 49 , figs. 1,2 , 4 ; text-fig. 22 b, c), from the basal Campanian of Texas, but the latter has two rows of lateral tubercles in the adolescent stage. In $R$, hataii the umbilical tubercles are somewhat above the umbilical shoulder and some ribs are slightly elevated at the shoulder. Therefore the umbilical tubercle could be regarded as the lower lateral one, if the elevation at the umbilical shoulder became distinct. In $R$. durhami, however, the lower lateral tubercle is distinctly weaker than the tubercle at the umbilical shoulder. It is finally absorbed by the rib on the large outer whorl, which accordingly is apparently trituberculate. But the mode of trituberculation is different in the two species. Such a difference and a similar change with growth can be seen also in some species of Texanites and Protexanites with regard to the tubercles on the flank. Young (1963) made mention of the Texanites stangeri-like inner whorl of $R$. durhami, but he did not clearly show whether the side keel on the small inner whorl is entire or wavy. The inner whorl of $R$. hataii resembles the Protexanites-like inner whorl of Texanites kawasakii (to be described in Part III of this monograph).

Occurrence.-The locality of the holotype is recorded merely as the Ikushumbets. The matrix indicates a calcareous nodule in black mudstone. This lithology suggests the main part of the Upper Yezo Group which is referable to the Urakawan (i.e. Coniacian and Santonian) in the Ikushumbets valley.

\section{References Cited}

The references cited in Part II are mostly found in the bibliography in Part I. They are not repeated here. The following is a supplementary list of references which should be added to the bibliography.

BRINkMANn, Roland (1935): Die Ammoniten der Gosau und des Flysch in den nördlichen Ostalpen. Beiträge zur Kenntnis der alpinen Oberkreide Nr. 2. Mitt. geol. Staatsinst. Hamburg, (15), 1-14.

FALlOT, J.E. (1885): Études géologiques des étages moyens et supérieures du terrain crétacé dans le sud-est de la France. Ann. Sci. Géol., 18, (1), 1-202, pls. 1-6.

Matsumoto, Tatsuro, Obata, I., Maeda, S. and Sato, Teruo (1964): Yabeiceras (Cretaceous ammonites) from Futaba, northeast Japan. Trans. Proc. Palaeont. Soc. Japan, N.S., (56), 
322-331, p1. 48.

SornAy, Jacques [Ed.] (1957): Lexique Stratigraphique International, 1, Europe, Fasc. 4a, France, Belgique, Pays-Bas, Luxembourg. Fasc. 4avi, Crétacé, p. 1-403, maps; Congr. Géol. Intern. - Comm. Stratigr., Paris.

Stromceck, A. von (1859): Beitrag zur Kenntnis des Pläners über der Westphälischen Steinkohlenformation. Zeitschr. deutsch. geol. Gesell., 11, 27-77.

Tsushima, Konroku, Tanaka, K., Matsuno, K. and Yamaguchi, S. (1958): Tappu. Expl. Text. Geol. Map Japan. Scale 1:50,000, 66p (in Japanese) + 8p (abstract in English), Geol. Surv. Japan. 
Tatsuro Matsumoto

A Monograph of the Collignoniceratidae from Hokkaido

Part II

Plates $36[19]-43[26]$ 
Plate 36 [19] 


\section{Explanation of Plate 36 [19]}

Fig. 1. Peroniceras sp. nov. (?) aff. P. platycostatum van Hoepen .............. Page 214 GK. H5494, from loc. 11-2506, Hobetsu, Iburi Province, southern central Hokkaido (Coll. W. Hashimoto). Lateral (a) and ventral (b) views and a retouched suture (c), nearly natural size (very slightly reduced). 


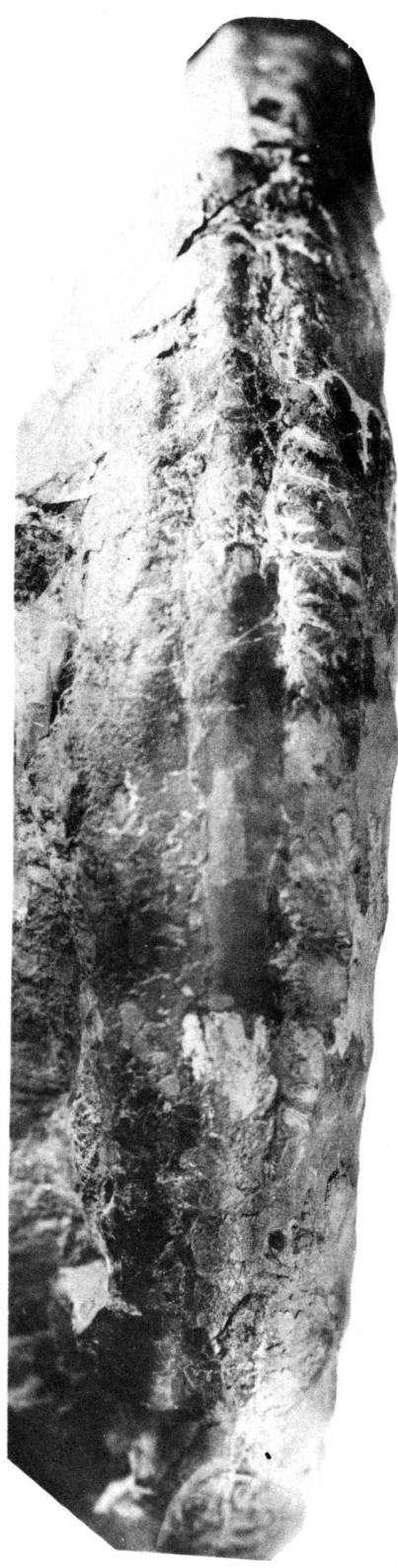

$1 \mathrm{~b}$

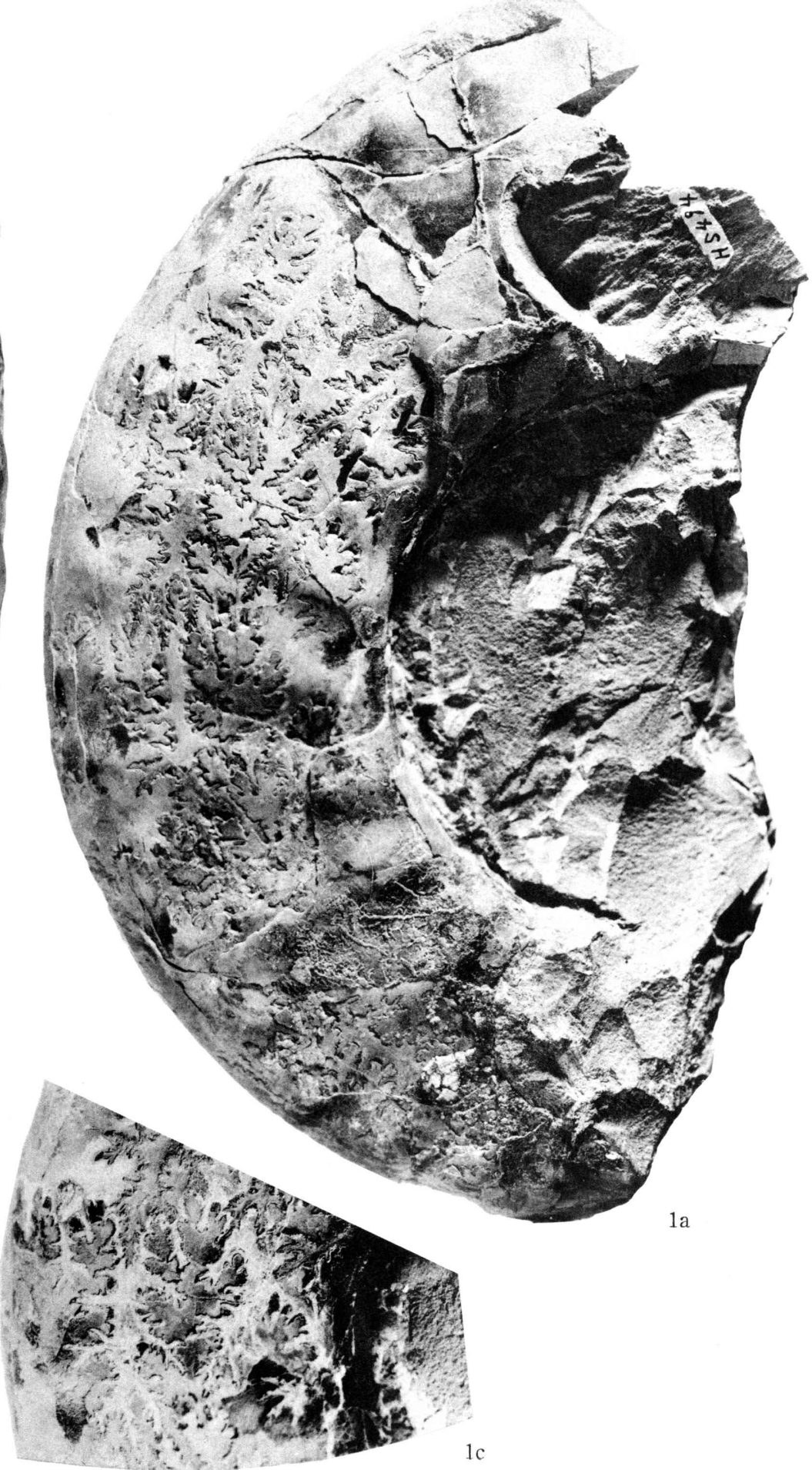

T. Matsumoto: Collignoniceratidae [Pl. 19] 
Plate 37 [20] 


\section{Explanation of Plate 37 [20]}

Fig. 1. Peroniceras sp. nov. (?) aff. P. czoernigi (Redtrinacher)............ Page 216 Mikasa High School Coll. No. 119, from the Ikushumbets, Ishikari Province, central Hokkaido. Lateral (a) and ventral (b) views, $\times 1.5$.

Fig. 2. Cobbanoceras ninakawai (YABE and SHImizu) .................... Page 223 Holotype, IGPS. 8026, from Yanagi-no-sawa, a branch of the Sanushibe, Iburi Province, south central Hokkaido. Lateral (a) and ventral (b) views, $\times 1.5$.

Fig. 3. Cobbanoceras tanakai gen. et sp. nov........................... Page 220 Holotype, GK. H5522, from 1oc. NH279-a, unit Uf of Upper Yezo Group, the Obirashibets, Rumoi area, Teshio Province, northwest Hokkaido (Coll. K. TANAKA). Lateral view, $\times 1$ (See Pl. 38, Fig. 1a-c). 

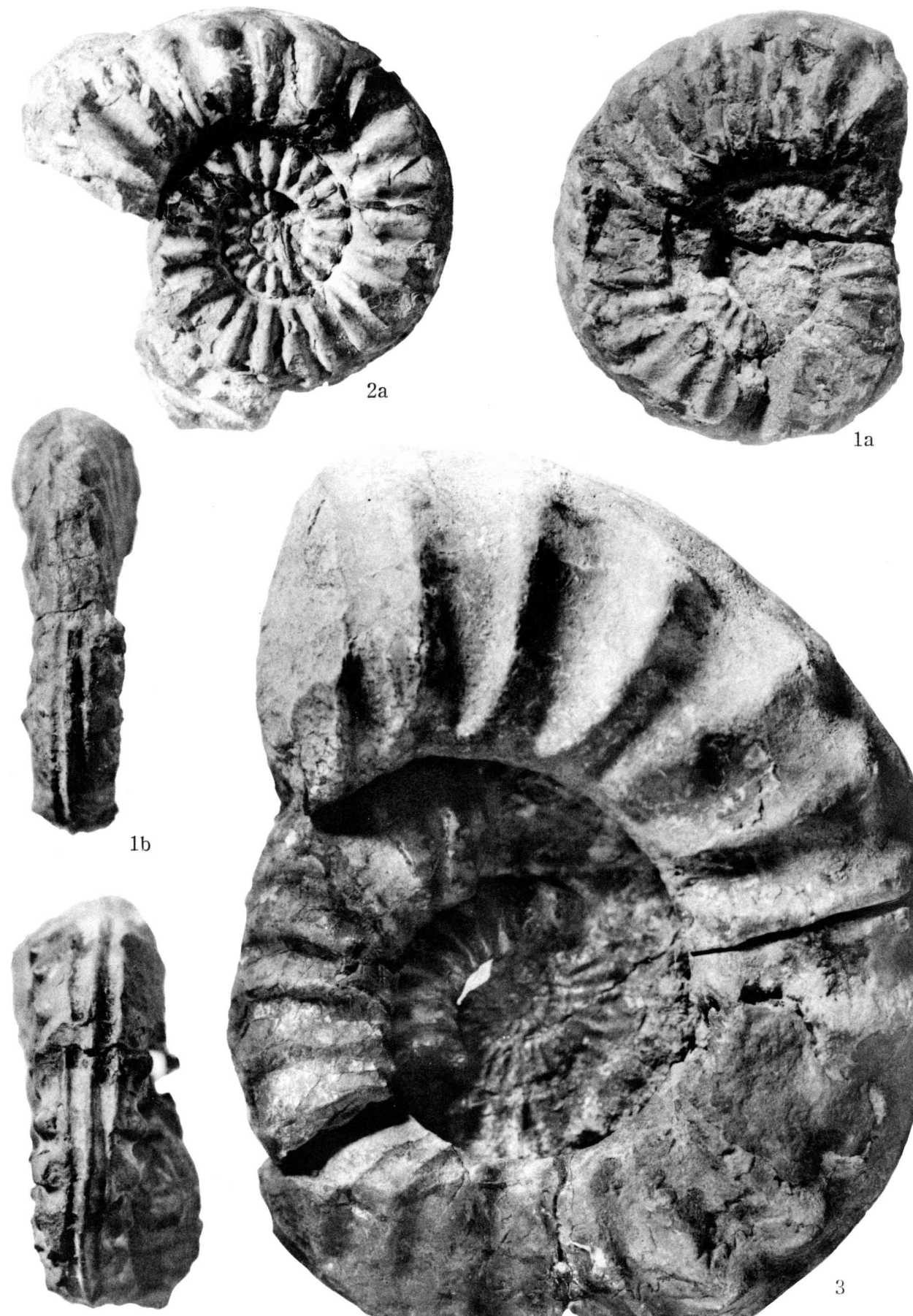

$2 b$

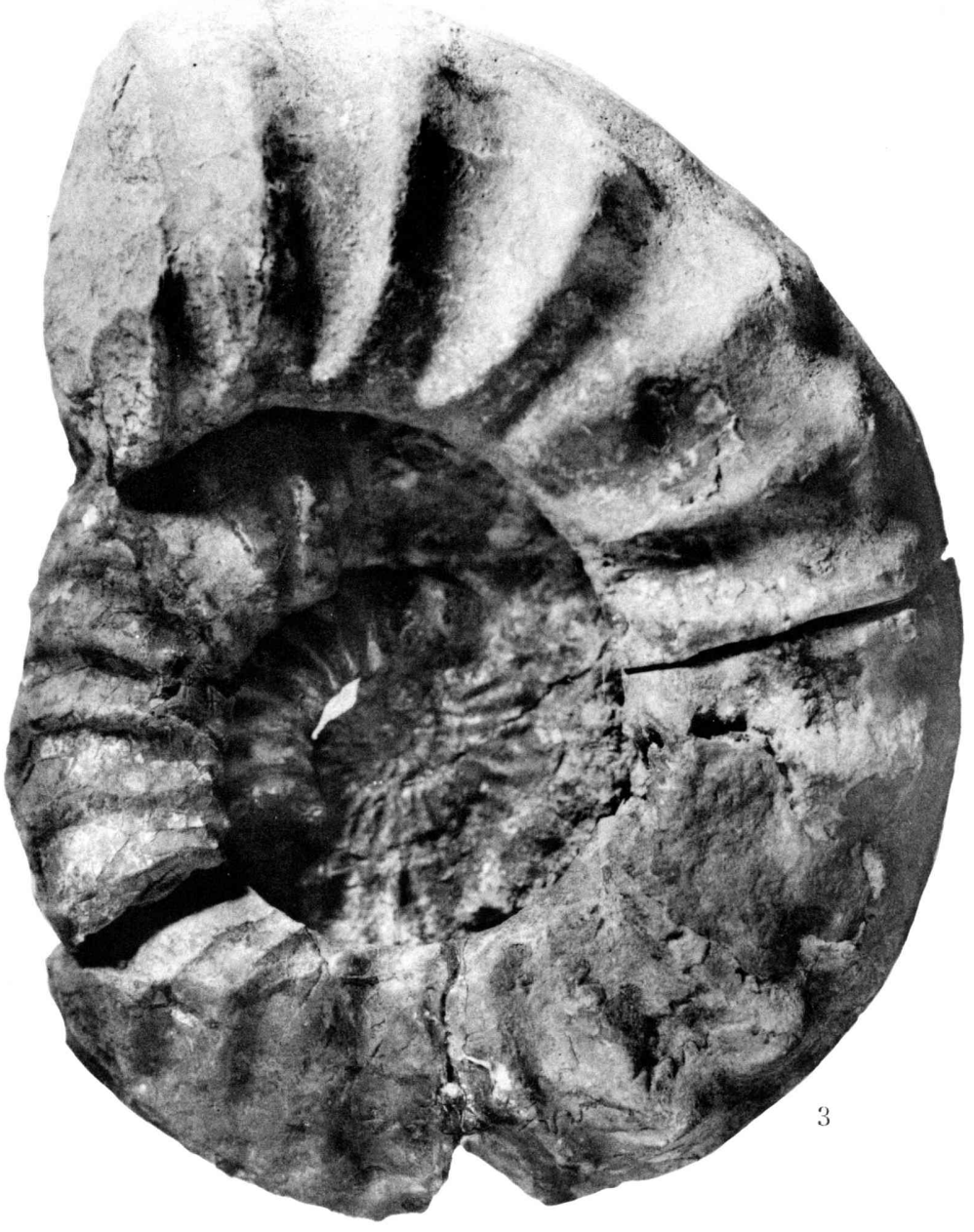

T. Matsumoto: Collignoniceratidae [PI. 20] 
Plate 38 [21] 


\section{Explanation of Plate 38 [21]}

Fig. 1. Cobbanoceras tanakai gen. et sp. nov......................... Page 220 Holotype, GK. H5522, from loc. NH279-a, unit Uf of Upper Yezo Group, the Obirashibets, Rumoi area, Teshio Province, northwest Hokkaido (Coll. K. TANAKA). Lateral (a) and ventral (b) views and a natural cross section (c), $\times 1$ (Fig. 1a slightly reduced). 

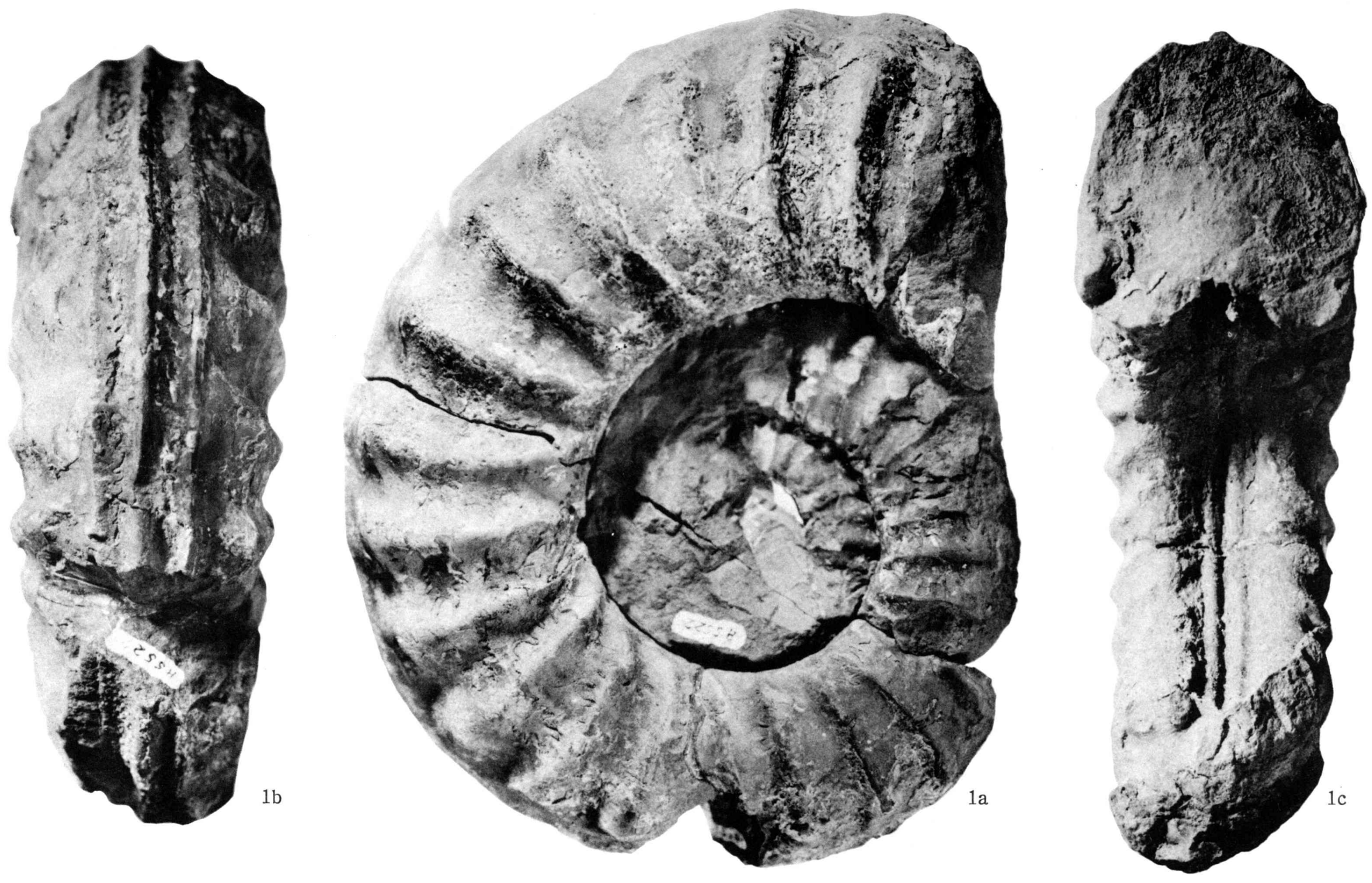

T. Matsumoto: Collignoniceratidae [Pl. 21] 
Plate 39 [22] 


\section{Explanation of Plate 39 [22]}

Fig. 1. Cobbanoceras tanakai gen. et sp. nov......................... Page 220 Paratype, GK. H5523, from loc. NH671, unit Ug of Upper Yezo Group, a branch of the Obirashibets (Forestry section 197), Rumoi area, Teshio Province, northwest Hokkaido

(Coll. K. TANAKA). Lateral view, $\times 0.9$.

Figs. 2, 3. Sornayceras sp. cf. S. propoetidum (Redtenbacher) ............... Page 233

2. Mikasa High School Coll. No. 122, from the upper stream of the Ikushumbets, Ishikari Province, central Hokkaido. Lateral (a) and ventral (b) views, $\times 1.5$.

3. Mikasa High School Coll. No. 123, from Yoshiyachi-zawa, a branch of the Ikushumbets, Ishikari Province, central Hokkaido. Lateral (a) and ventral (b) views, $\times 1.5$. 


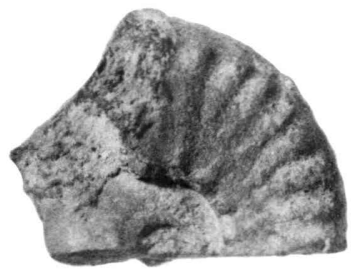

$2 a$

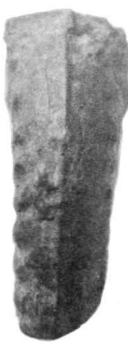

$2 \mathrm{~b}$

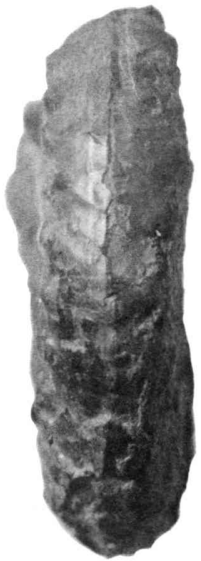

3
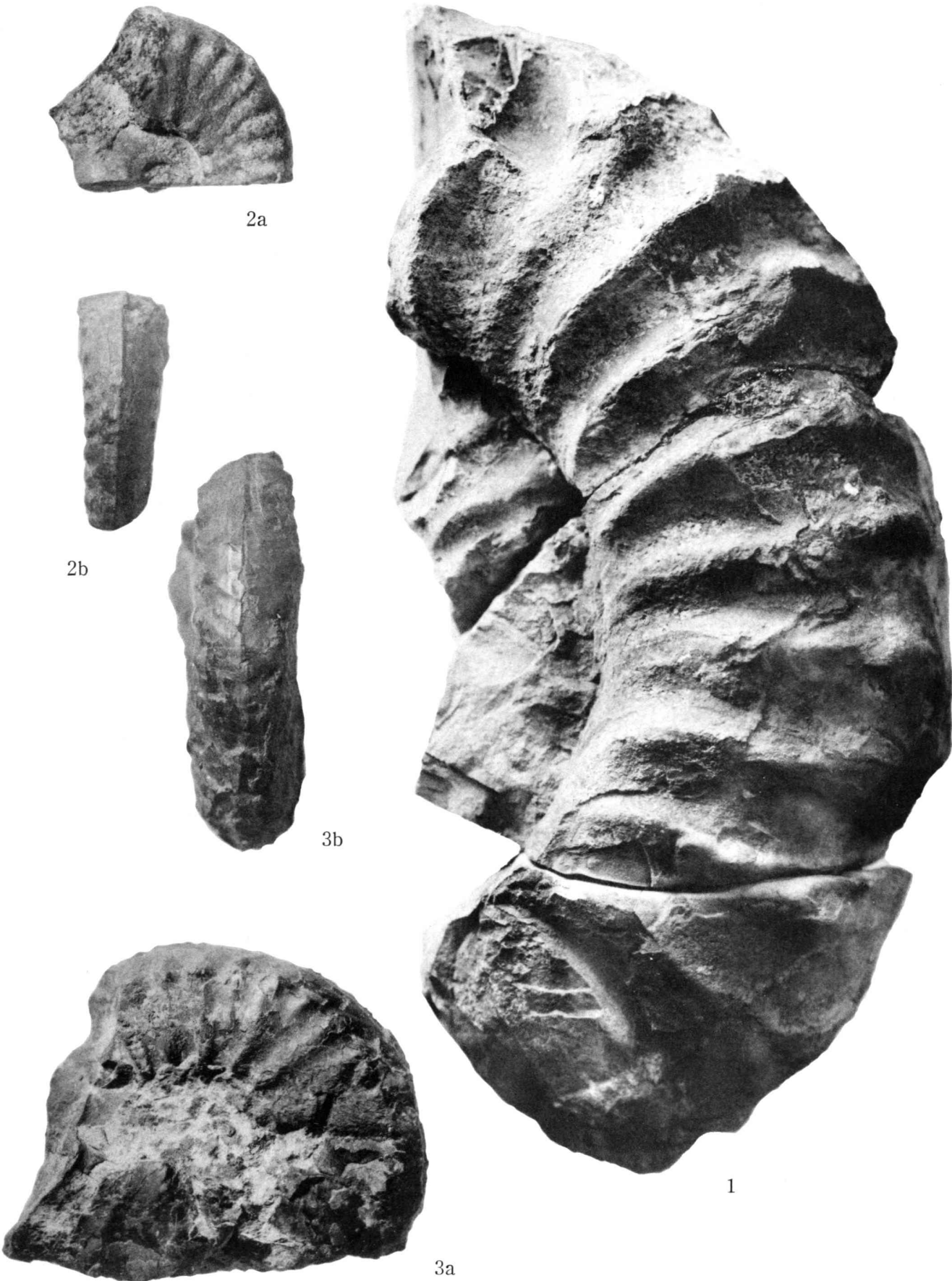

T. Matsumoto: Collignoniceratidae [Pl. 22] 
Plate 40 [23] 


\section{Explanation of Plate 40 [23]}

Fig. 1. Sornayceras proteus gen. et sp. nov........................ Page 227

Holotype, GK. H5438, from Yoshiyachi-zawa, a branch of the Ikushumbets, Ishikari Province, central Hokkaido. Lateral (a, b) and ventral (c) views, $\times 1$. In Fig. 1b a part of the outer whorl is removed to show the inner whorl. 


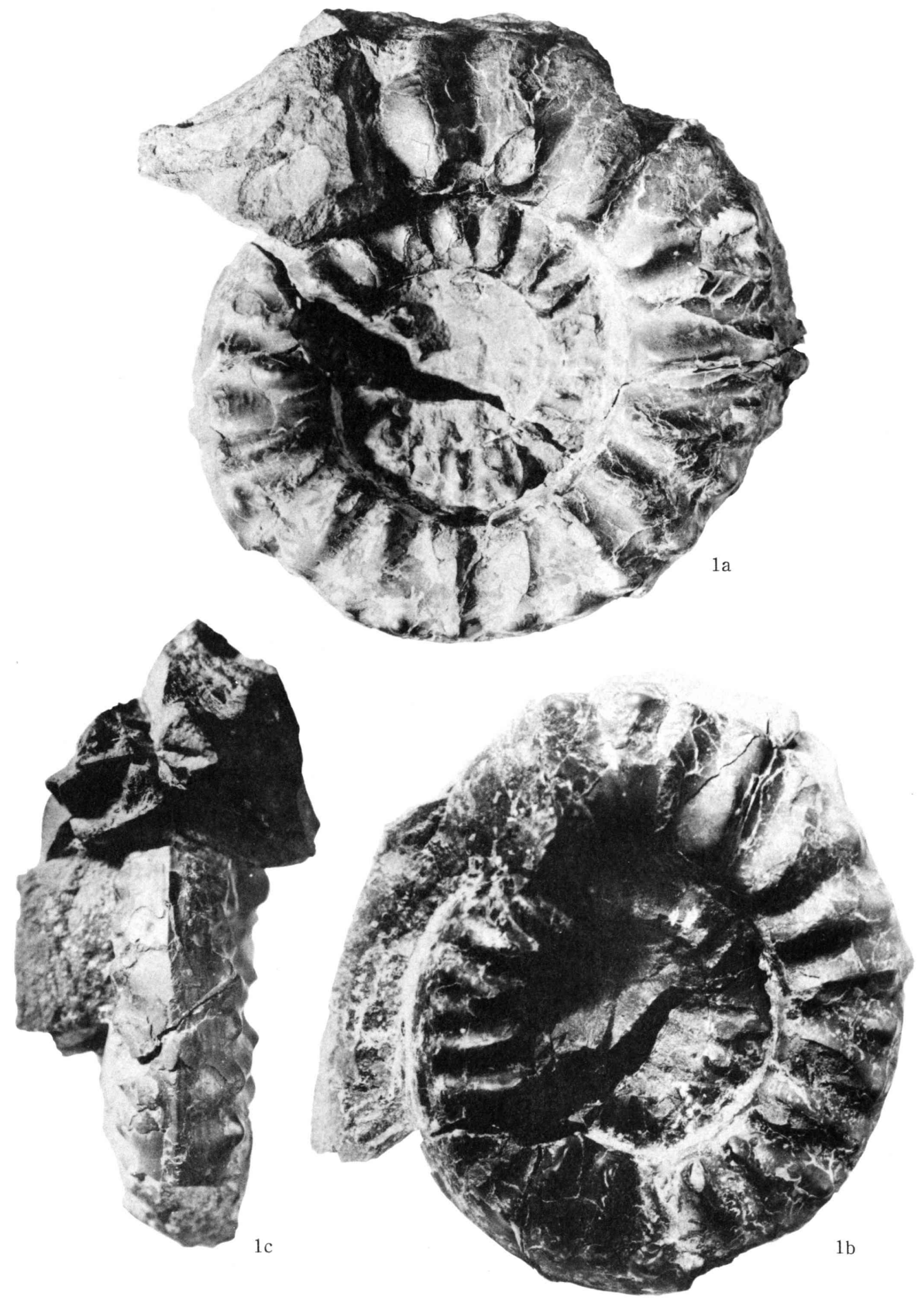

T. Matsumoto: Collignoniceratidae [Pl. 23] 
Plate 41 [24] 


\section{Explanation of Plate 41 [24]}

Fig. 1. Sornayceras sp. cf. S. proteus gen. et sp. nov..................... Page 227

A fragmentary whorl of a large shell, Mikasa High School Coll. No. 25, from the Ichi-no-sawa, a branch of the Ikushumbets, Ishikari Province, central Hokkaido. Lateral (a) and ventral (b) views, $\times 0.9$. Only one side of the whorl is preserved. 

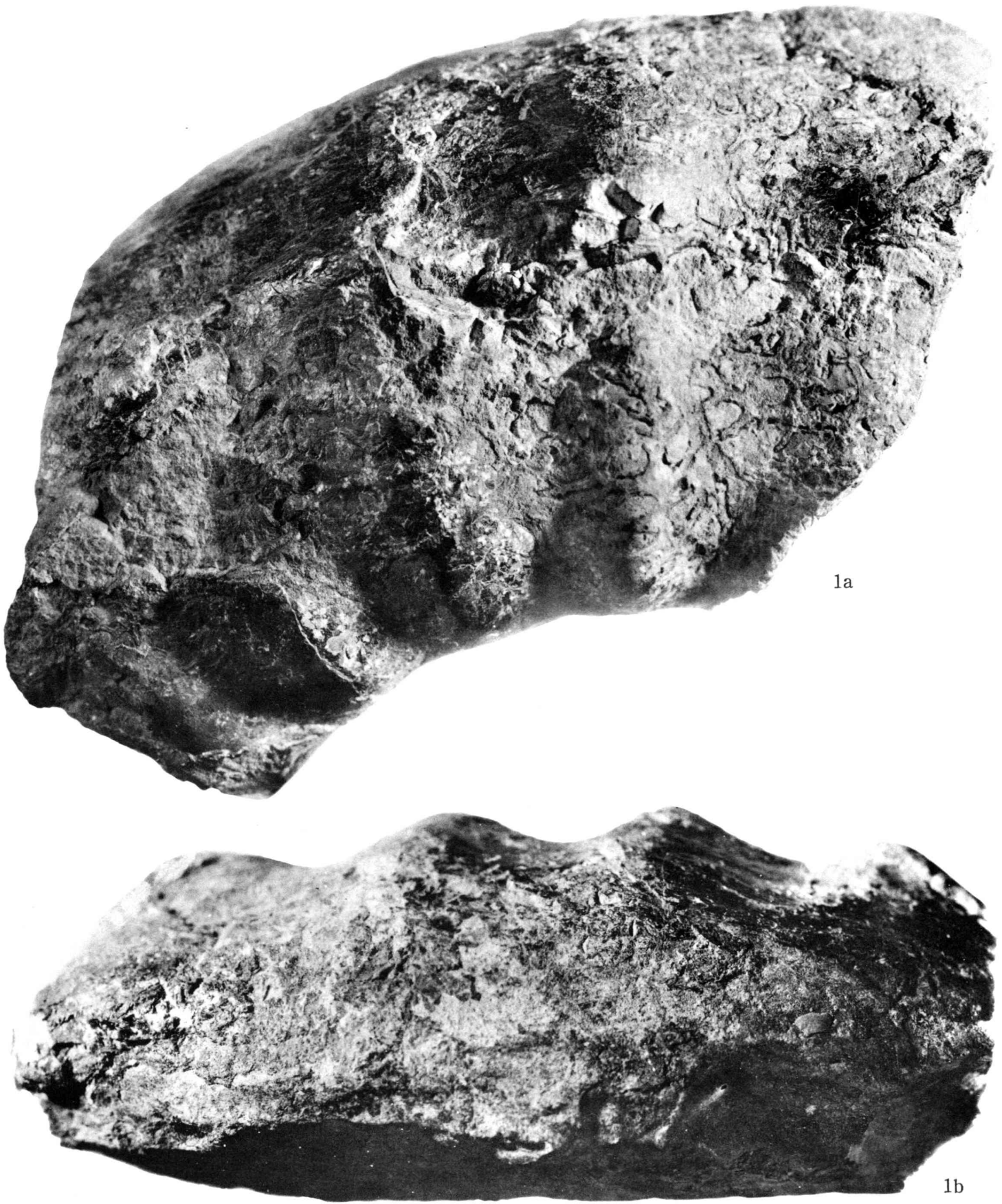

T. Matsumoto: Collignoniceratidae [Pl. 24] 
Plate 42 [25] 


\section{Explanation of Plate 42 [25]}

Figs. 1, 2. Sornayceras omorii gen. et sp. nov. ....................... Page 230

1, Paratype, Mikasa High School Coll. No. 120, from the Ikushumbets, Ishikari Province, central Hokkaido. Lateral (a) and ventral (b) views, $\times 1$.

2. Holotype, GK. H5493, from the upper main stream of the Ikushumbets, somewhat above the confluence with the Inari-zawa, Ishikari Province, central Hokkaido. Lateral (a) and ventral (b) views; lateral view of a part of the other side (c), showing the spiral lirae crossing the ribs, all in natural size $(\times 1)$.

Fig. 3. Reymentites hataii gen. et sp. nov. ............................ Page 240 Holotype, IGPS.54746, from the Ikushumbets, Ishikari Province, central Hokkaido. Two lateral (a, b), ventral (c) and frontal (in part sectional) (d) views, $\times 1$. 
$1 \mathrm{~b}$
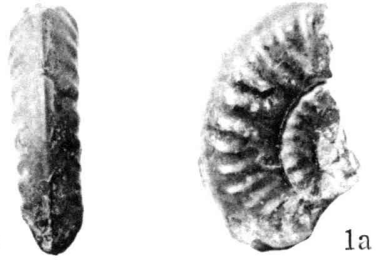

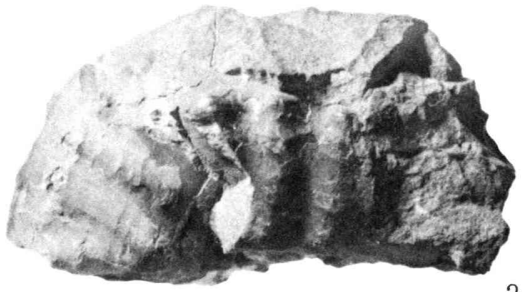

$2 \mathrm{c}$

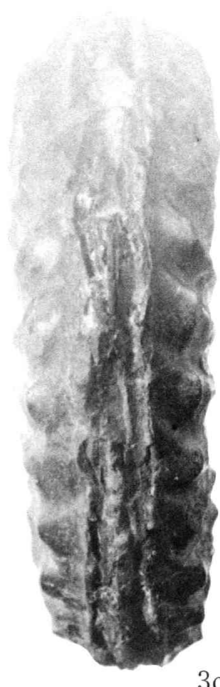

$3 \mathrm{c}$
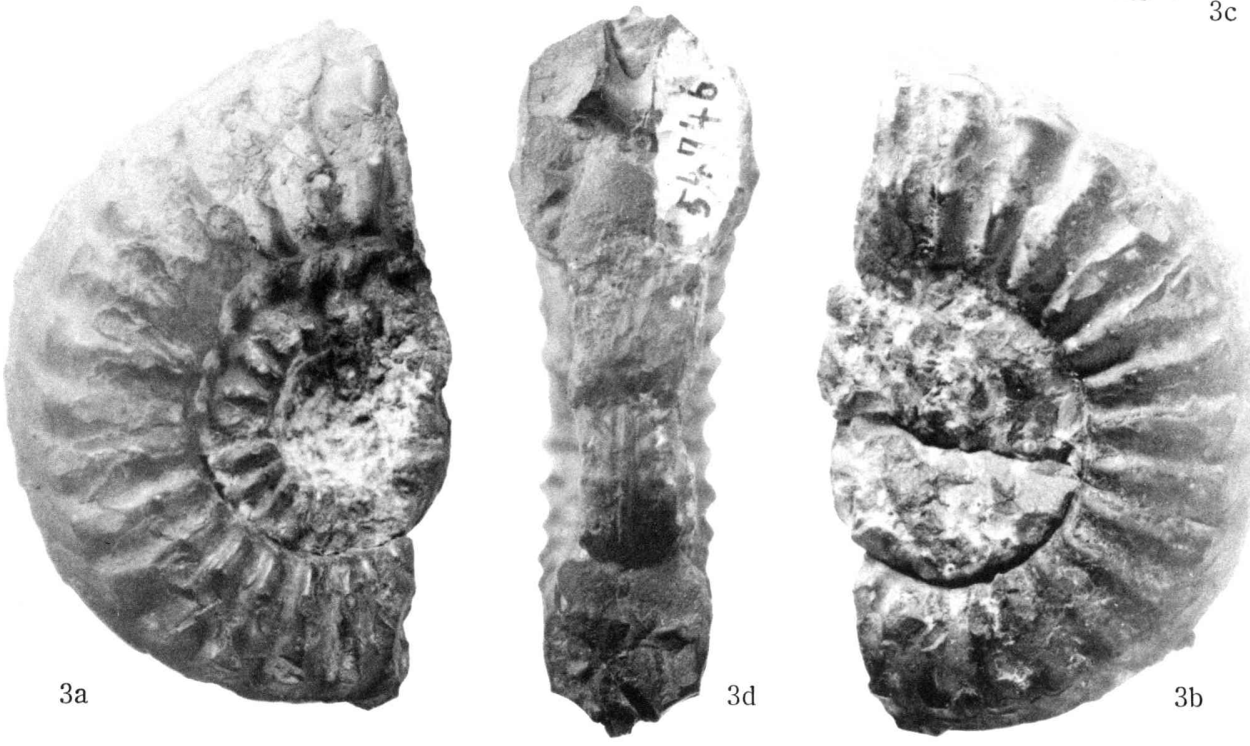

T. Matsumoto: Collignoniceratidae [PI. 25] 
Plate 43 [26] 


\section{Explanation of Plate 43 [26]}

Fig. 1. Ishikariceras binodosum gen. et sp. nov. ...................... Page 236 Holotype, GK. H5576 (originally Mikasa High School Coll.), from the upper reaches of the Ichi-no-sawa, a branch of the Ikushumbets, Ishikari Province, central Hokkaido. Two lateral (a, b) views; ventral view of the last quarter whorl (c); lateral (d) and ventral (e) views of the inner whorl, all in natural size $(\times 1)$. 


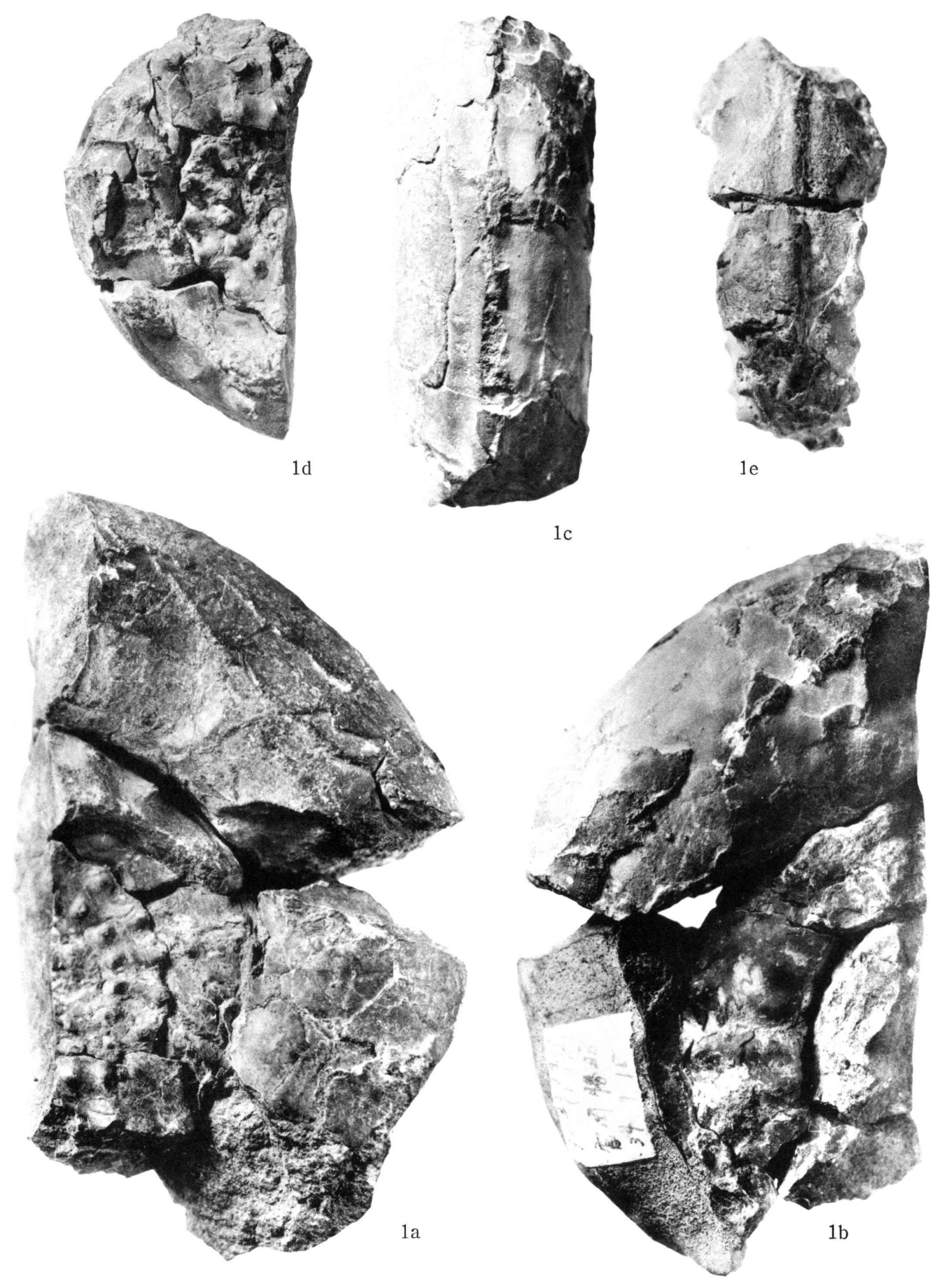

T. Mațsumoto: Collignoniceratidae [Pl. 26] 